US Army Corps of Engineers ${ }_{\circledast}$

Engineer Research and

Development Center

\title{
Preliminary Feasibility and Risk Analysis of a Carbon Dioxide Barrier at Brandon Road Lock and Dam
}

John M. Nestler, David L. Smith, Christa M. Woodley,

September 2017

Robert D. Moser, and Pete C. Flanagan 
The U.S. Army Engineer Research and Development Center (ERDC) solves the nation's toughest engineering and environmental challenges. ERDC develops innovative solutions in civil and military engineering, geospatial sciences, water resources, and environmental sciences for the Army, the Department of Defense, civilian agencies, and our nation's public good. Find out more at www.erdc.usace.army.mil.

To search for other technical reports published by ERDC, visit the ERDC online library at http://acwc.sdp.sirsi.net/client/default. 


\section{Preliminary Feasibility and Risk Analysis of a Carbon Dioxide Barrier at Brandon Road Lock and Dam}

John M. Nestler

Limnotech

501 Avis Drive

Ann Arbor, MI 48108

David L. Smith and Christa M. Woodley

Environmental Laboratory

U.S. Army Engineer Research and Development Center 3909 Halls Ferry Rd.

Vicksburg, MS 39180

Robert D. Moser

Geotechnical and Structures Laboratory

U.S. Army Engineer Research and Development Center

3909 Halls Ferry Rd.

Vicksburg, MS 39180

Pete C. Flanagan

U.S. Army Corps of Engineers Chicago District

231 S. LaSalle St

Chicago, IL 60604

Final report

Approved for public release; distribution is unlimited. [or a restricted statement]

Prepared for Headquarters, U.S. Army Corps of Engineers

Washington, DC 20314-1000

Under U4345698 USACE Investigation for Use of Carbon Dioxide $\left(\mathrm{CO}_{2}\right)$ as an Aquatic Nuisance Species Deterrent Support and Coordination with the University of Illinois and Illinois Department of Natural Resources 


\section{Abstract}

A fish barrier using elevated aqueous carbon dioxide $\left(\mathrm{CO}_{2}\right)$ concentrations is proposed for Brandon Road Lock and Dam to prevent the spread of Asian carp into the Great Lakes. However, a $\mathrm{CO}_{2}$ barrier has never been assessed for potential environmental impacts, human health and safety risks, or for mechanical or structural deterioration of the lock and dam. Environmental impacts of the barrier will be modest and are restricted to the barrier vicinity. Nonetheless, significant asphyxia threats $\left(\mathrm{CO}_{2}\right.$ is denser than air) exist in closed spaces (e.g., barges, ship hulls, and the lock chamber when the miter gates are closed). Potential exists for drowning or vessel sinking because $\mathrm{CO}_{2}$ bubbles reduce water density and the buoyant forces needed to float a human body or vessel. The increased risk caused by the reduction in buoyancy cannot be estimated without first knowing the design and operation of the $\mathrm{CO}_{2}$ delivery system. Lastly, elevated aqueous $\mathrm{CO}_{2}$ concentrations will increase the concrete deterioration rate. However, little information exists that can be used to estimate the potential for structural or mechanical damage. Constructing an elevated $\mathrm{CO}_{2}$ barrier is feasible at the Brandon Roads Lock and Dam; however, this comes with potentially substantial risks to human health and safety, and project integrity. More detailed studies should be conducted after the design and operation of an elevated $\mathrm{CO}_{2}$ barrier are known.

DISCLAIMER: The contents of this report are not to be used for advertising, publication, or promotional purposes. Citation of trade names does not constitute an official endorsement or approval of the use of such commercial products. All product names and trademarks cited are the property of their respective owners. The findings of this report are not to be construed as an official Department of the Army position unless so designated by other authorized documents. 


\section{Contents}

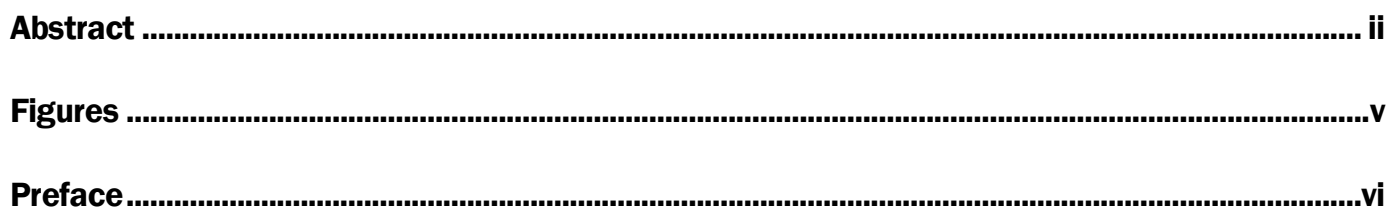

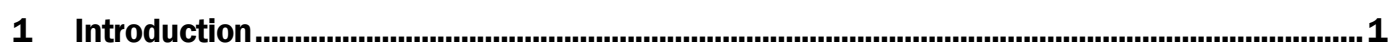

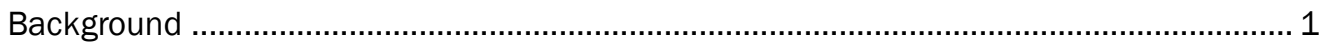

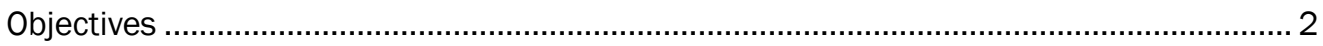

2 Significant Physical and Operational Aspects of the Brandon Road Lock and Dam ............. 3

2.1 Potential fish passages at BRLD.................................................................... 3

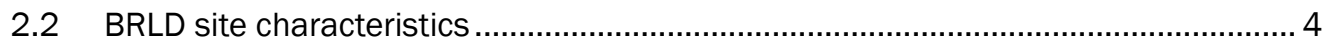

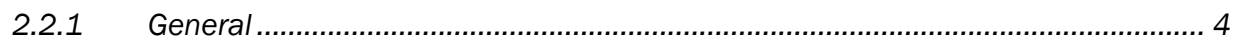

2.2.2 Navigation chamber...................................................................................... 5

2.2.3 Navigation chamber filling and emptying culverts ............................................. 5

2.2.4 Approach channel connecting BRLD and the Des Plaines River ........................... 7

2.2.5 Water exchange processes between the approach channel and the Des

Plaines River.............................................................................................................. 8

2.2.6 Effects of tow (or other vessel) traffic on conditions in the approach channel and BRLD ..................................................................................................... 9

2.2.7 Sources of water mixing within the approach channel and navigation chamber 10

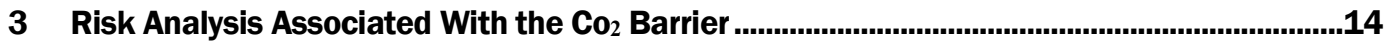

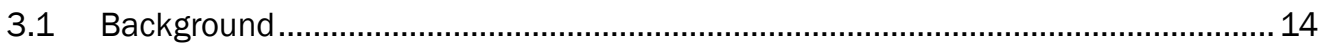

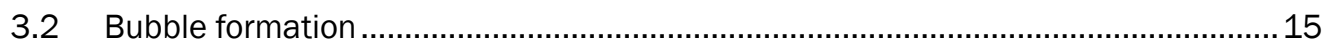

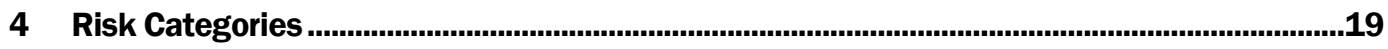

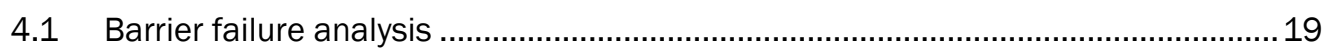

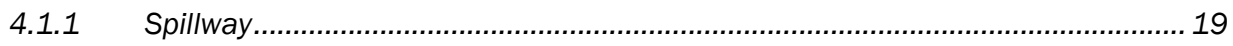

4.1.2 Lock chamber filling and emptying culverts..................................................... 19

4.1.3 Lock chamber and approach channel ........................................................... 20

4.1.4 Summary of effects............................................................................................ 21

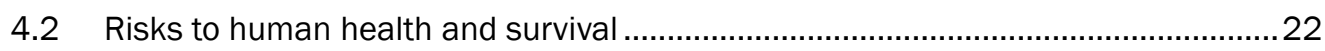

4.2.1 $\mathrm{CO}_{2}$ intoxication, loss of consciousness, and asphyxiation ..................................22

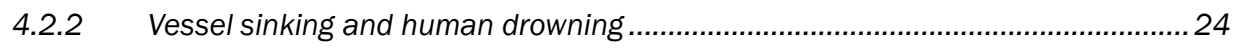

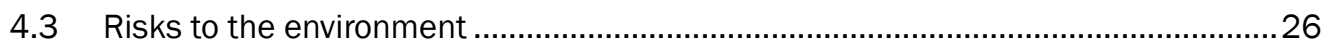

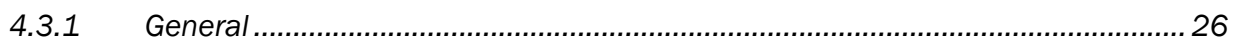

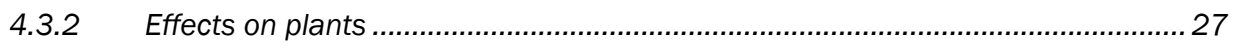

4.3.3 Effects on fishes and shell-building organisms.............................................27

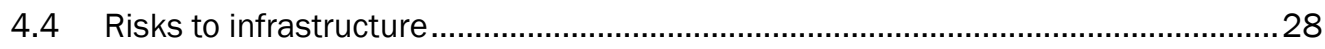

4.5 Mitigating effects of elevated $\mathrm{CO}_{2}$ through aeration ..........................................32

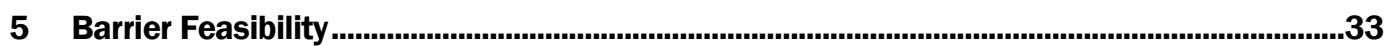




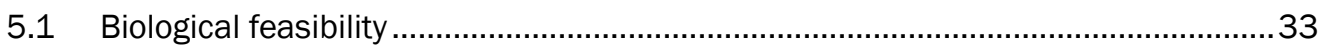

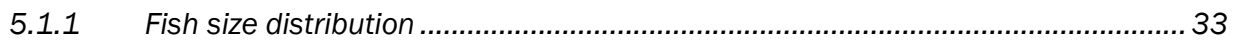

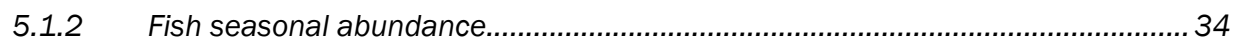

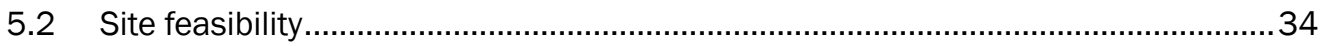

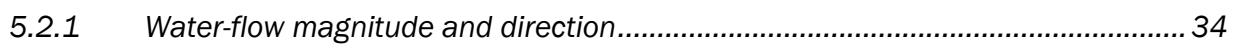

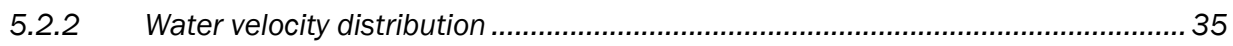

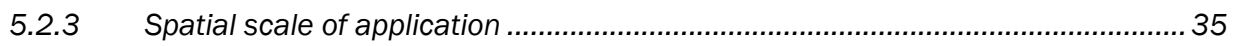

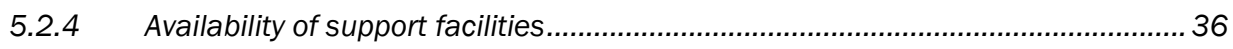

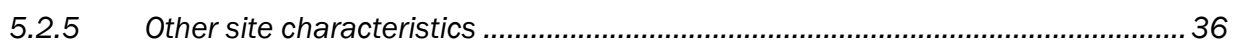

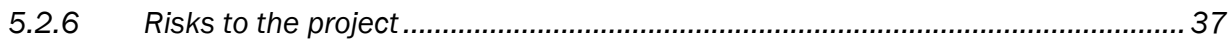

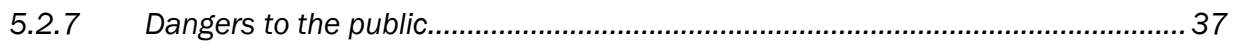

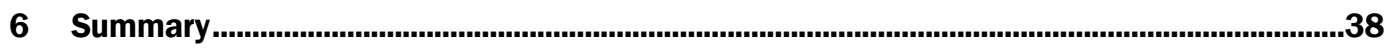

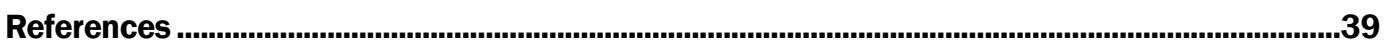

Report Documentation Page 


\section{Figures}

\section{Figures}

Figure 1. Google Maps satellite photograph of $\mathrm{CO}_{2}$ barrier downstream of the navigation chamber of Brandon Road Lock and Dam (BRLD), Joliet, Illinois.

Figure 2. Plan view of BRLD showing water distribution and regulating system used to

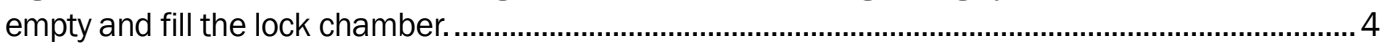

Figure 3. Expanded view of the upstream end of a typical lock on the Illinois Waterway.................... 6 Figure 4. Picture taken during emptying of the navigation chamber at BRLD. Note highly turbulent conditions immediately downstream of the lock and for some distance downstream into the approach channel. 


\section{Preface}

This study was conducted for the U. S. Army Corps of Engineers (USACE) Chicago District. Funding Account Document U4345698; USACE Investigation for Use of Carbon Dioxide $\left(\mathrm{CO}_{2}\right)$ as an Aquatic Nuisance Species Deterrent Support and Coordination with the University of Illinois and Illinois Department of Natural Resources. The Project Manager was Ms. Felicia Kirksey.

The work was performed by the Water Quality and Contaminant Modeling Branch (EPW) of the Environmental Processes and Engineering Division (EP-ED), U.S. Army Engineer Research and Development Center, Environmental Laboratory ERDC-EL. At the time of publication, Ms. Dorothy H. Tillman was Chief, CEERD-EPW, Warren Lorenz was Chief, CEERD-EP. The Deputy Director of ERDC-EL was Dr. Jack Davis and the Director was Dr. Beth Fleming.

The Commander of ERDC was COL Bryan S. Green and the Director was Dr. David W. Pittman. 


\section{Introduction}

\section{Background}

A number of structural and behavioral barriers have been either used or proposed to manage the distribution and movement of fishes. In some cases, the management goal was to prevent desirable fishes from entering locations such as hydropower dams where they could be injured or killed (Taft et al. 1985; Schilt 2007). More recently, management attention has shifted to using new technologies (USACE 2012a) to prevent the spread of aquatic nuisance species (ANS) into new areas. Unlike development of fish protection barriers, development of physical (e.g., screens) and behavioral (e.g., strobe lights or acoustic fields) barriers for the control of ANS have been particularly vexing, leaving little margin for error. Any non-pass barrier can be defeated. The failure could be disastrous if even a few ANS pass because of their ability to disperse rapidly, reproduce in large numbers, outcompete native species, disrupt natural food webs, and destabilize ecosystems (Asian Carp Regional Coordinating Committee 2014; Ricciardi and MacIsaac 2011). Therefore, the requirement for 100\% effectiveness is particularly true for interconnecting waterways and river navigation systems that potentially allow for long-range expansion of ANS throughout large parts of the continental USA.

Recently, interest has increased in the use of barriers (including elevated carbon dioxide $\left(\mathrm{CO}_{2}\right)$ concentrations) to limit the range extension of Asian carp into the Great Lakes Ecosystem (USACE 2012a). Laboratory and smallscale studies indicate that elevated $\mathrm{CO}_{2}$ levels in a waterway may function as a highly effective barrier to Asian carp movement. Effectiveness may be increased if an elevated $\mathrm{CO}_{2}$ barrier is used in conjunction with another behavioral barrier, such as an electrical barrier, to target multiple sensory modalities (Nestler et al. 1995), thereby increasing the likelihood of refusal to pass by targeted ANS.

Intermediate and large-scale tests are being considered in the near future at the Brandon Road Lock and Dam (BRLD), located on the Des Plaines River (part of the Chicago River Sanitary and Ship Canal), to prevent movement of Asian carp into the Great Lakes. This report provides background information to help determine the feasibility of a $\mathrm{CO}_{2}$ barrier and to identify several of the risks associated with the barrier. 


\section{Objectives}

The objectives of this report are the following:

- describe significant physical and operational aspects of the BRLD important for design and deployment of a potential $\mathrm{CO}_{2}$ barrier,

- provide information to support feasibility studies of other potential sites and identify any opportunities and challenges to $\mathrm{CO}_{2}$ barrier deployment on the Des Plaines River,

- identify and consider risks to members of the public and barrier operators,

- identify potential for adverse impacts, and

- assess the possibility of unintended outcomes.

Appendix C of the U.S. Army Corps of Engineers Great Lakes and Mississippi River Interbasin Study (GLIMRS) study (USACE 2014) provides an existing risk analysis describing the impacts on the Great Lakes Ecosystem of failures of barriers to prevent ANS expansion. This report does not duplicate the risks described in the Appendix $\mathrm{C}$ risk analysis nor does it describe or analyze any risks associated with the construction of the $\mathrm{CO}_{2}$ barrier. Instead, it focuses on risks to the environment and risks to human health of a deployed $\mathrm{CO}_{2}$ behavioral system (based on inferences about the size and operation of the system). 


\section{Significant Physical and Operational Aspects of the Brandon Road Lock and Dam}

\subsection{Potential fish passages at BRLD}

The use of behavioral barriers to prevent the spread of ANS has been recommended for BRLD (USACE 2014). Two locations are suitable for the installation of a behavioral barrier, either in the navigation chamber or in the downstream approach channel to the navigation chamber. (Figures 1 and 2). The first step in evaluating the feasibility of a $\mathrm{CO}_{2}$ barrier requires a general description of the site and a specific description of each route that a fish could pass upstream through the dam. Fish can potentially pass upstream three different ways based on examination of BRLD plans located in the Master Water Control Manual (USACE 1996): through the lock chamber during a vessel lockage or a test lockage, through the water distribution culverts that empty and fill the lock chamber, and through the spillway.

Figure 1. Google Maps satellite photograph of $\mathrm{CO}_{2}$ barrier downstream of the navigation chamber of Brandon Road Lock and Dam (BRLD), Joliet, Illinois.

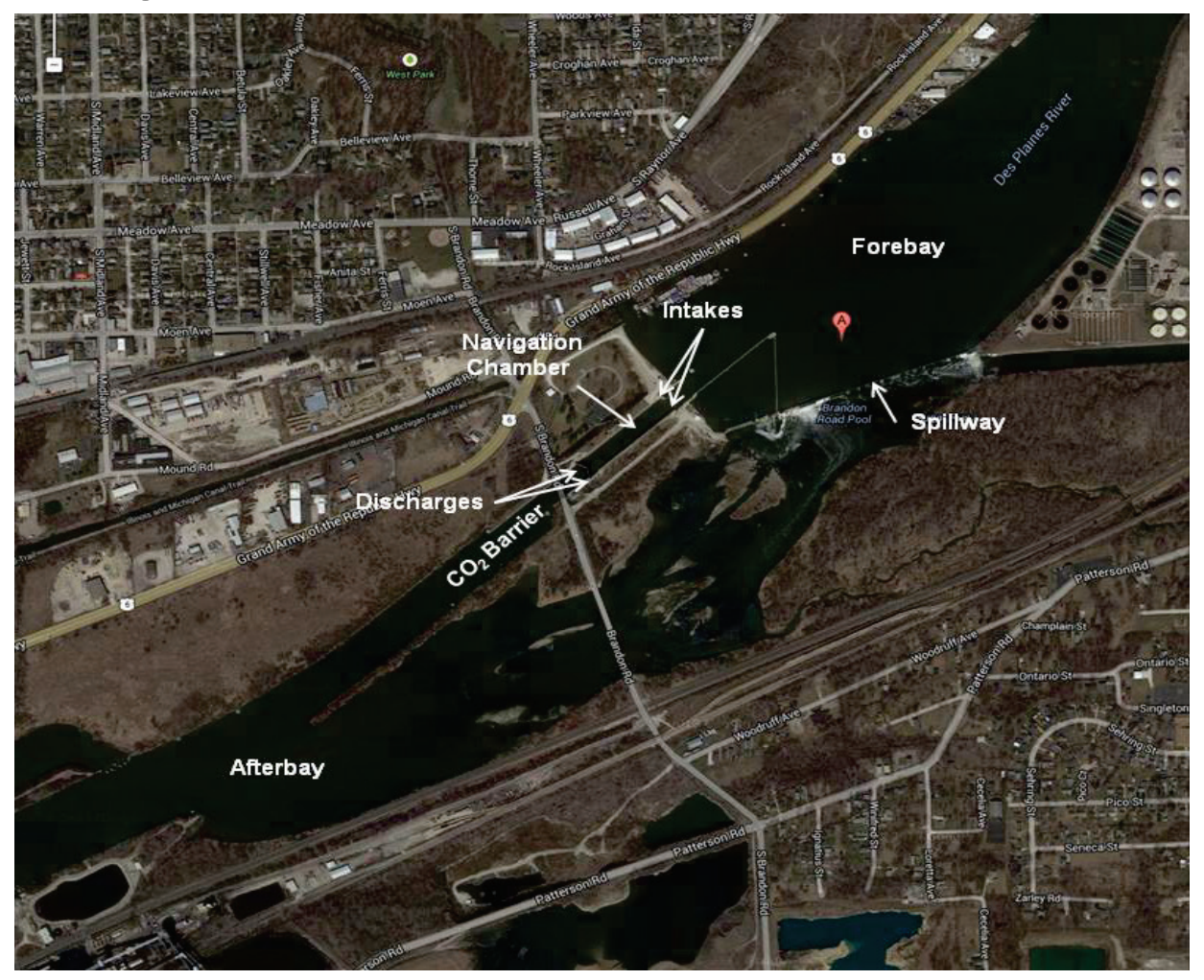


Figure 2. Plan view of BRLD showing water distribution and regulating system used to empty and fill the lock chamber.

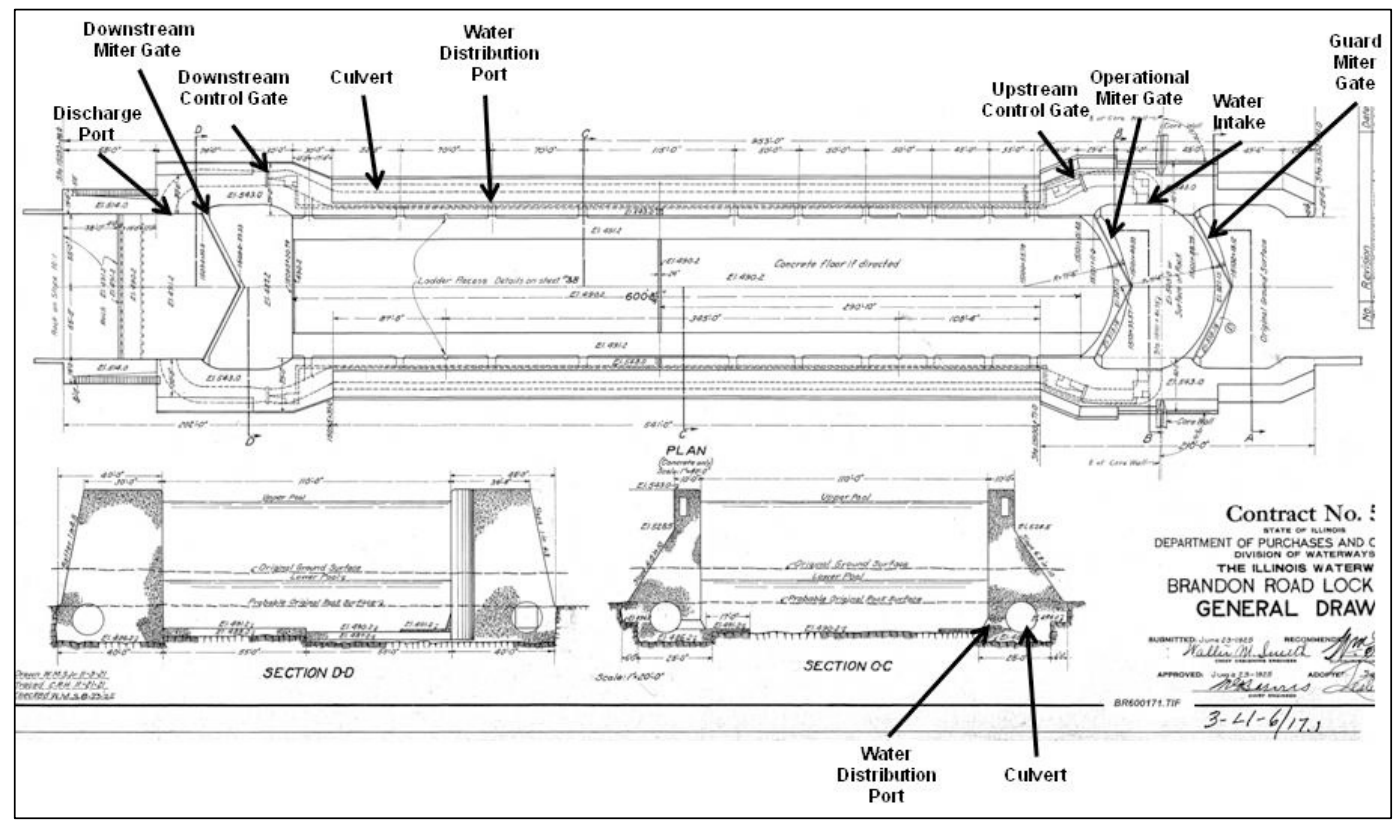

\subsection{BRLD site characteristics}

\subsubsection{General}

The BRLD site (Figure 1) is located in Joliet, Illinois, on the Des Plaines River and is part of the Chicago River Sanitary and Ship Canal System. The Chicago River is a major tributary of the Mississippi River. The total length of the dam is $2391 \mathrm{ft}$ and consists of an earthen embankment that is $822 \mathrm{ft}$ long and a concrete section that is $1569 \mathrm{ft}$ long. Gates located along the concrete section of the dam control the water levels within the upstream pool of the BRLD. This concrete section includes $1521 \mathrm{ft}$ of moveable or gated sections, $30 \mathrm{ft}$ of concrete overflow, and $18 \mathrm{ft}$ of boiler house.

Insight into how and when fish bypass dams can be gained by comparing BRLD to navigation dams located on the Mississippi River. Fish are known to pass upriver through or over spillways on the Mississippi River when the elevation differences between the forebay and tailwater are minimal or when the river completely submerges certain outlet structures (Wilcox et al. 2004). The gated section of BRLD contains 21 tainter gates (50 ft wide $\times 2 \mathrm{ft}, 3.5$ in. high), 6 non-operable (closed with bulk heads) sluice gates, and 16 headgates $(16 \mathrm{ft}$ high $\times 15 \mathrm{ft}$ wide) of which, eight are not operable (closed with bulkheads). The elevation difference between the tailwater and forebay of the dam is a useful surrogate to assess the likelihood that fish could pass through the spillway gates. Normal elevation difference between tailwater and headwater elevations is $34 \mathrm{ft}$. 
Highest and lowest stages upstream of BRLD were $540.5 \mathrm{ft}$ (about $1.5 \mathrm{ft}$ above normal operational stage) and $537.2 \mathrm{ft}$ (about $1.3 \mathrm{ft}$ below normal operation), respectively. Normal tailwater elevation (no flow) is $504.5 \mathrm{ft}$. Highest and lowest tailwater stages are $513.3 \mathrm{ft}$ (about $8.8 \mathrm{ft}$ above normal level) and $501.1 \mathrm{ft}$ (no flow condition-about $3.4 \mathrm{ft}$ below normal level), respectively. The least difference in tailwater elevation (difference between lowest headwater [537.2 ft] and highest tailwater elevation $(513.3 \mathrm{ft})$ is $23.9 \mathrm{ft}$ (USACE 1996). The minimum elevation difference is unlikely to occur because high elevations are associated with floods and low elevations are associated with droughts.

\subsubsection{Navigation chamber}

Fish intermittently pass through lock chambers during ship passage; and in some cases, special fish lockages are used to pass fish upstream during periods of low navigation traffic (Smith et al. 2013). Therefore, knowledge of the physical and operational attributes of the navigation lock is critical when designing an effective fish barrier. In addition, the dimensions and operations of BRLD will directly influence the design parameters and placement of the $\mathrm{CO}_{2}$ barrier in either in the navigation chamber or the approach channel. The BRLD navigation chamber, shown in Figure 2, is $110 \mathrm{ft}$ wide by $600 \mathrm{ft}$ long and includes two pairs of upstream miter gates and a pair of downstream gates that are used during routine navigation operation. The sill depth of the lower end of the navigation chamber, under normal tailwater elevation, is $15 \mathrm{ft}$. This allows the navigation chamber to operate effectively, even during unusually low tailwater water levels. The lift of the navigation lock under normal forebay and tailwater elevations is $34 \mathrm{ft}$; however, this will vary with the differences between forebay and tailwater elevations.

\subsubsection{Navigation chamber filling and emptying culverts}

Fish can also pass through the water distribution systems that are used to fill and empty lock chambers (Scott and Hevel 1991). In many ways, the water distribution system resembles a Borland fish lock system that is used to pass fish upstream of a dam (Smith et al. 2013). At BRLD, the navigation chamber filling and emptying system consists of a $12 \mathrm{ft}$ diameter controlled culvert with 10 rectangular side ports $(5 \mathrm{ft} \mathrm{W}$ by $3.5 \mathrm{ft} \mathrm{H}$ ). These ports, shown in Figures 2 and 3, run along the base of each lock wall and are used to fill and empty the lock during navigation operation. The upstream end of the culvert is protected by a trash rack located between the operational and 
guard miter gates (Figure 3). The culvert terminates in an unguarded (no trash racks) discharge port located just downstream of the navigation chamber. Water flow through each culvert is controlled by a pair of hydraulically operated roller lift valves (roller bearings facilitate the raising and lowering of the gates) that are located at each end. A complete lock cycle takes 34 minutes (ignoring the time required for a vessel to enter or depart the chamber). Filling the lock takes about 19 minutes; lock emptying taking about 15 minutes. The passage of a typical large tow of 15 barges requires that the tow be separated into two parts. Each part of the tow is locked separately and then reconstituted on the other side of the lock. The need to separate a large tow into two parts and lock each part separately triples (to pass one section, return for the next section, and then pass that section) the amount of time require for lockage.

Figure 3. Expanded view of the upstream end of a typical lock on the Illinois Waterway.

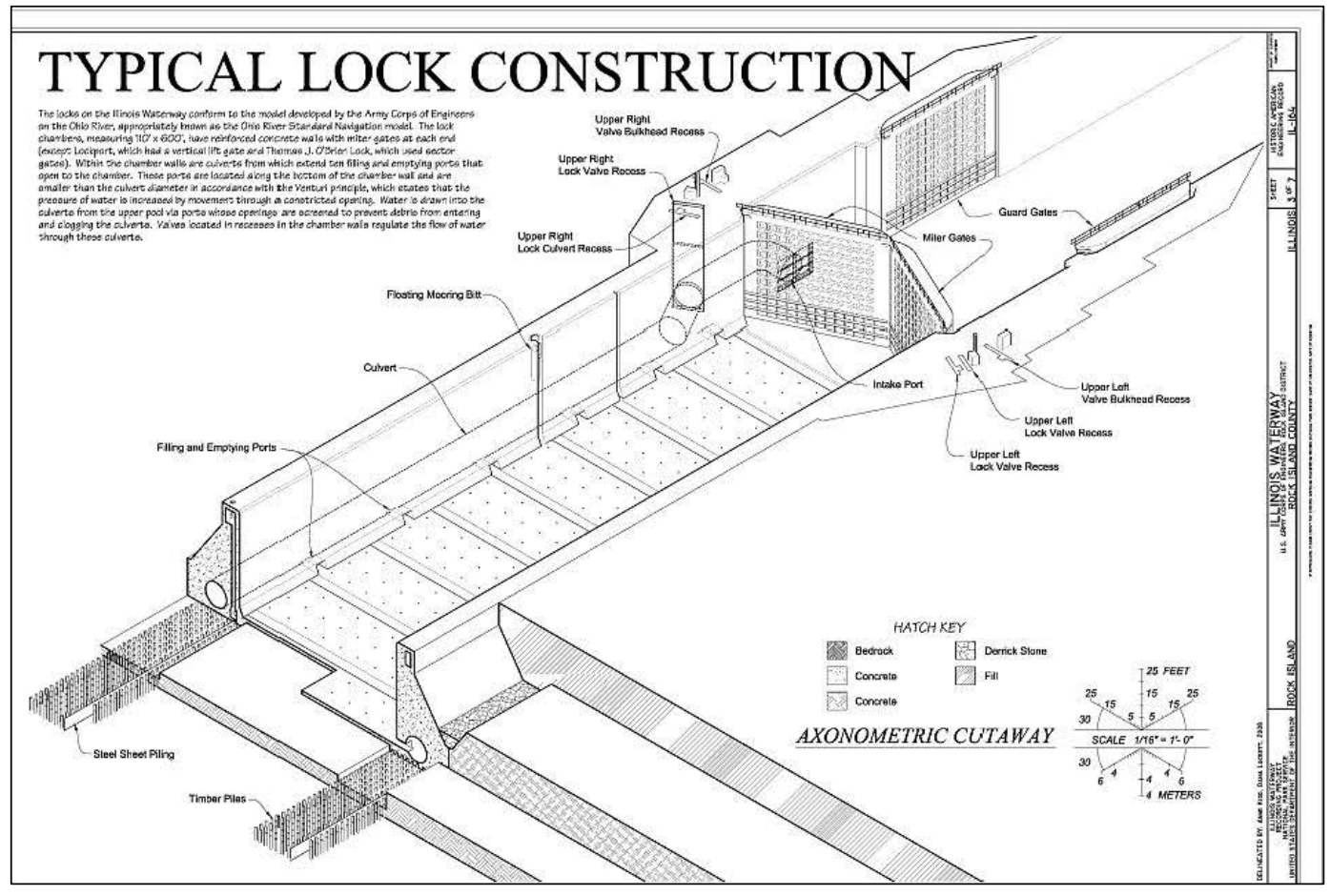

Although studies that document the movement of fish through the lock culverts are rare, their existence indicates that passage of ANS through them must be considered as part of any ANS barrier or containment strategy. As an example, sauger (Stizostedion canadense) are bottomoriented fish that use the lock culverts at a number of Tennessee River dams to gain entry into the lock chamber. The fish exit the lock chamber through the upstream miter gates when the gates open to pass ships (Scott and Hevel 1991). These movements are important for maintaining sauger 
populations in tailwaters of the Tennessee River (though results are not directly quantified). The success of sauger passage strongly correlates to the design and location of the downstream culvert discharge ports. That is, discharge ports located in deep water and near the river thalweg appear to attract the greatest number of migrating sauger. Conversely, discharge ports located in shallow water and far from the thalweg (as is the case for BRLD) are not effective at attracting sauger or other bottom-dwelling fish, but instead might attract surface-oriented fish such as Asian carp. Scott and Hevel (1991) also recommend that the upstream valve on the culverts be slightly opened to release a small, constant attracting flow at the culvert discharge ports. This description of the upstream passage of sauger through the culverts of a navigation lock highlight the importance of possible small changes in operation for BRLD that will encourage the passage of desirable fishes and, by extension, discourage the passage of ANS.

\subsubsection{Approach channel connecting BRLD and the Des Plaines River}

The BRLD navigation chamber connects to the main channel of the Des Plaines River by a separate approach channel as shown in Figure 1. Knowledge of the dimensions and operational conditions in the approach channel is important for four reasons. First, the volume of the approach channel (without the navigation chamber) represents the maximum volume of water that would need to be charged with elevated $\mathrm{CO}_{2}$ concentrations if a barrier or barrier component is located in the approach channel. Second, the exchange rate of water in the approach channel will determine the amount of time required to elevate $\mathrm{CO}_{2}$ concentrations to effective levels. Third, the water exchange processes at the downstream end of the approach channel will represent a loss of $\mathrm{CO}_{2}$ from the approach channel (via bulk flow) and reduce the $\mathrm{CO}_{2}$ gradient (and hence decrease the ability of Asian carp to detect the barrier). Fourth, releases from the navigation chamber during lock emptying may flush water with elevated $\mathrm{CO}_{2}$ out of the approach channel and into the Des Plaines River.

Based on measurements made from satellite imagery of the BRLD (Figure 1), the approach channel is estimated to be $2100 \mathrm{ft}$ long and $218 \mathrm{ft}$ wide with an average (deeper mid-channel and shallower near shore) depth assumed to be approximately $10 \mathrm{ft}$ (the navigation channel is maintained to $9.0 \mathrm{ft}$ ), yielding a volume of about 4,600,000 $\mathrm{ft}^{3}$. The amount of water discharged from the navigation chamber during a typical 15 minute emptying is the area of the chamber $(110 \mathrm{ft} \mathrm{W} \times 600 \mathrm{ft} \mathrm{L})$ times the height of a normal lock lift ( $34 \mathrm{ft}$ ), which is about $2,200,000 \mathrm{ft}^{3}$ or about half of the 
volume of water in the approach channel. The navigation chamber water volume capacity at normal tailwater elevation (i.e., when empty) is $600 \mathrm{ft} \mathrm{L}$ $\times 110 \mathrm{ft} \mathrm{W} \times 15 \mathrm{ft} \mathrm{D}$ (sill depth at normal tailwater elevation), equivalent to $990,000 \mathrm{ft} 3$. The precise volume is determined by tailwater elevation.

\subsubsection{Water exchange processes between the approach channel and the Des Plaines River}

Understanding the water exchange between the approach channel and the Des Plaines River is vital. The downstream end of the approach channel the source of Asian carp that could pass the locks through the navigation chamber. Mixing of Des Plaines River water without elevated $\mathrm{CO}_{2}$ with water in the approach channel with potentially elevated $\mathrm{CO}_{2}$ would dilute the $\mathrm{CO}_{2}$ concentration created by the barrier. The dilution of $\mathrm{CO}_{2}$ from the level thought to induce a flight response will subsequently decrease the effectiveness of the barrier. Water mixing will also distort the plume of rising $\mathrm{CO}_{2}$ bubbles, possibly affecting the efficiency of gas transfer and the integrity of the boundary of the plume. In addition, the mixing of the water bodies will reduce the gradient of $\mathrm{CO}_{2}$, potentially making the barrier less detectable to upstream-moving fish and making the boundary of the barrier less discrete. Therefore, approaching fish will lack a clear, distinct stimulus to identify the direction they must swim to reduce $\mathrm{CO}_{2}$ exposure.

There are several hydraulic processes that create or affect water exchange between the downstream end of the approach channel and the Des Plaines River. These exchange processes will, in turn, affect the concentration of $\mathrm{CO}_{2}$ of the behavioral barrier and thus its effectiveness:

1. Water exchange results from the complex hydraulics occurring at the confluence of the approach channel with the Des Plaines River. The spatial extent and magnitude of mixing at the confluence will depend upon the water release rate from the BRLD spillway and tailwater elevation. The extent of mixing can be estimated from field studies or from multidimensional computational dynamics modeling.

2. Further water exchange will occur as a tow of barges (or other vessel types) transits from the Des Plaines River into the approach channel, displacing water from the approach channel into the Des Plaines River. Turbulent mixing will occur from the prop wash of the towboat and the resulting wave action generated along the shoreline as displaced water from the approach channel moves around and under the tow, 
3. Water exchange will also occur as a tow (or other vessel type) exits the approach channel and as water from the Des Plaines River replaces the water displaced by the tow. In addition, the prop wash of the towboat as it nears the exit of the approach channel will further force Des Plaines River water into the approach channel, reducing $\mathrm{CO}_{2}$ concentrations, obfuscating the $\mathrm{CO}_{2}$ gradient, and disrupting the integrity of the rising plume of elevated $\mathrm{CO}_{2}$.

\subsubsection{Effects of tow (or other vessel) traffic on conditions in the approach channel and BRLD}

In addition to the physical and operational characteristics of the BRLD, it is important to consider the effects of both the presence and movement of a large tow (or other large vessel) on the conditions within the approach channel and the navigation lock. The presence of a fully loaded tow of 15 barges will substantially decrease the volume of water in the approach channel. Information for typical barge dimensions on the Des Plaines River could not be found. However, the HNTB Corporation (2009) used $35 \mathrm{ft} \mathrm{W} \times$ $195 \mathrm{ft} \mathrm{L}$ as the dimensions for a hopper barge when calculating the impact forces on bridge piers in the event of a collision. These design dimensions seem reasonable based on an assessment of barge size frequency analysis for Lock and Dam 27 on the Mississippi River, where 53,628 of 61,593 total barges (87\%) fell within a width of 28 to $36 \mathrm{ft}$ and a length of 195 to $259 \mathrm{ft}$ (HNTB Corporation 2009). Based on this analysis, it is estimated that the average barge displacement is $35 \mathrm{ft} \mathrm{W} \times 195 \mathrm{ft} \mathrm{L} \times 9 \mathrm{ft} \mathrm{D}$, or about 61,000 $\mathrm{ft} 3$. A modern large tow of 15 barges (USACE 2012b) plus the towboat (assumed to be equal in displacement to that of a fully loaded hopper barge) awaiting passage in the approach channel of BRLD would displace about $16 \times 61$,ooo $\mathrm{ft}^{3}$, or 976, ooo $\mathrm{ft}^{3}$. This volume is nearly equivalent to the capacity of the lock chamber with open downstream miter gates at the normal tailwater elevation (i.e., 990,000 ft3). Reducing the approach channel volume by the displacement of a large tow of barges $\left(4,600,000 \mathrm{ft}^{3}\right.$ - 976,000 ft3) yields a channel capacity of about 3,624,000 ft3. From these calculations, it appears that the emptying phase of a locking cycle with a large tow in the approach channel awaiting entry to the lock chamber would flush slightly less than about two-thirds $(2,200,000 \mathrm{ft} 3 / 3,624,000 \mathrm{ft} 3)$ of the approach channel with upstream water. Proportional flushing volume will increase at a lower tailwater elevation because the volume of the approach channel will decrease. 


\subsubsection{Sources of water mixing within the approach channel and navigation chamber}

For this paper it is assumed that a future $\mathrm{CO}_{2}$ behavioral barrier will use either a bubbler, as used in reservoir re-aeration (McAliley and D'Adamo 2010) or a Venturi jet injector as used in the aeration chambers of treatment plants (Baylar et al. 2006) or used to inject ozone or $\mathrm{CO}_{2}$ into swimming pools (Professional Pool Operators of America 2010). For these systems to work efficiently, the integrity of the designed bubble plume must be maintained. Wuest and Lorke (2003) describe this as natural (i.e., wind induced) turbulent mixing in lakes. Their study is useful for understanding how turbulent mixing caused by water displacement and prop wash affect the exchange of physical constituents, such as heat, kinetic energy, momentum, and matter (e.g., gases, vapor, and aerosols). Chanson (2008) provides insight into the advective diffusion of air bubbles within the turbulent flows of rivers. It is important to consider that these same processes occur in the prop wash of the tow (or other vessel) or in the flows that occur from the displacement of water created by a moving barge. For example, substantial air entrainment begins with a water velocity of about $1.0 \mathrm{~m}$-sec (Chanson 2008), although one must consider hydraulic variables other than water velocity. While maintaining the integrity of the bubble plume is important to:

1. create a sharply delineated (high gradient) zone of elevated $\mathrm{CO}_{2}$ easily detectable by Asian carp

2. ensure the high efficiency of mass exchange to maintain elevated $\mathrm{CO}_{2}$ concentrations

3. reduce loss of $\mathrm{CO}_{2}$ by minimizing unnecessary turbulence and thus reducing degassing of the inject $\mathrm{CO}_{2}$

4. maintain a sharp (high gradient) boundary between the elevated and nonelevated $\mathrm{CO}_{2}$ portions of the approach channel. An indistinct boundary, characterized by embedded zones of low $\mathrm{CO}_{2}$ caused by turbulence, may make it difficult for Asian carp to correctly localize the position of the elevated $\mathrm{CO}_{2}$ zone; and consequently, they may swim towards the lock chamber instead of away from the lock chamber.

There are several hydraulic processes that will affect water mixing within the approach channel:

1. To conserve mass, water displaced by the movement of the tow in either the upstream or downstream direction must escape from under and 
around the tow. The extent of turbulent mixing created by the displaced water will be related to water velocity. This will be determined by the speed of the tow relative to the ratio of the cross sectional area of the tow to the cross sectional area of the channel. Displaced water moving under the tow cannot degas because it is not in contact with air. However, the velocity associated with the displaced water will severely deteriorate the integrity of the rising plume of carbonated water. Deterioration of the integrity of the plume will reduce the gradient of $\mathrm{CO}_{2}$ concentrations and create a turbulent boundary, making it more difficult for a fish to localize the elevated $\mathrm{CO}_{2}$ boundary zone.

2. For a tow moving upstream from the Des Plaines River into the approach channel, water containing elevated $\mathrm{CO}_{2}$ concentrations will be displaced into the Des Plaines River. The prop wash from a towboat pushing barges upstream towards the navigation chamber can create complex threedimensional (3-D) flow fields as it displaces water (partially evacuating water from upstream) and advects the water downstream. The displaced water will likely be mixed with Des Plaines River water and dissipated by the prop wash from the towboat. The effects of bubbles created in the boat's wake depends on its size. The dynamics of large bubbles (greater than $2 \mathrm{~mm}$ diameter) is dominated by their large rise velocities and turbulent diffusion. The dynamics of small bubbles (less than $2 \mathrm{~mm}$ diameter) is dominated by turbulent diffusion and bubble volume loss from gas diffusion (Stewart and Miner 1987). The dynamics of both small and large bubbles will strip dissolved $\mathrm{CO}_{2}$ generated by the barrier system. The extent of the mixing and dissipation must be evaluated using field measurements or advanced simulation modeling as described in the companion report (Nestler 2014).

3. For a tow moving downstream from the approach channel into the Des Plaines River, water without elevated $\mathrm{CO}_{2}$ concentrations will be displaced into the approach channel and further distributed by the prop wash of the towboat into the approach channel. Almost certainly the combination of water displacement and mixing of elevated and non-elevated $\mathrm{CO}_{2}$ water by the prop wash will disrupt the integrity of the bubble plumes used to create elevated $\mathrm{CO}_{2}$ and potentially make the detection and localization of the elevated $\mathrm{CO}_{2}$ more difficult by targeted ANS. The increased turbulence of the prop wash will also increase the degassing rate of the elevated $\mathrm{CO}_{2}$ concentrations (Stewart and Miner 1987). Determining the extent of these impacts on the integrity of the bubble plume will require field measurements or advanced simulation modeling as described in the companion report. 
A typical 15-barge tow is too large to be locked as a single unit. It must be disassembled into two, and each part of the original tow is locked separately. It seems plausible that the prop wash and water displacement caused by additional towboat operations (e.g., required to assemble and disassemble the tow) will result in additional mixing. The discharge of water from the culverts during emptying of the lock chamber will create substantial turbulent mixing downstream of the navigation chamber (Figure 4). The turbulent mixing will strip $\mathrm{CO}_{2}$ from the water through increased atmospheric contact. The severity of the mixing will depend upon the difference in elevation between the tailwater and forebay water levels during the emptying phase of operation. Turbulent mixing will be greatest during the initial opening of the downstream lift gates, when the water elevation difference between the navigation chamber and tailwater is greatest. The energy level of turbulent mixing will decline with reduction in water elevation difference between the navigation chamber and tailwater. Turbulent mixing will be negligible when the downstream miter gates are opened. A worst case scenario for lock emptying occurs when a 15-barge tow approaches BRLD from downstream when water level within the lock chamber is in the elevated (full) position. The lock must empty to accept the first half of the tow and then must empty again before it can accept the rest of the tow. This sequence of empty ( 15 minutes) - fill (19 minutes) - empty (15 minutes) phases of lock operation will flush the approach channel in 49 minutes ( 15 minutes +19 minutes +15 minutes) plus the amount of time it takes to disconnect and reconnect the tow (i.e., 2 empty cycles $\times 2,200,000 \mathrm{ft} 3$ navigation chamber capacity during a lift $=4,400,000 \mathrm{ft} 3$ compared to the approach channel capacity of 4,600,000 $\mathrm{ft} 3$ without the displacement of a downstream tow or $3,624,000 \mathrm{ft} 3$ with the displacement of a typical large tow).

High water velocities downstream of the lock chamber will create turbulence in the approach chamber that will contribute to degassing of elevated $\mathrm{CO}_{2}$ concentrations. The average flow immediately downstream of the discharge ports during a 15 minute emptying cycle at BRLD is about $2500 \mathrm{ft}^{3} \mathrm{~s}^{-1}$ (lock chamber capacity for a normal lift of $34 \mathrm{ft}$ is $2,200,000 \mathrm{ft}^{3}$ divided by 900 seconds [ 15 minutes]), and an approximate peak is about $5000 \mathrm{ft}^{3} \mathrm{~s}^{-1}$. Using estimated approach channel dimensions of $218 \mathrm{ft} \mathrm{W} \times$ $10 \mathrm{ft}$ D yields a cross-sectional area of $2180 \mathrm{ft}^{2}$. The cross-sectionally averaged downstream water velocity during a lock emptying cycle then is about $1.1 \mathrm{fps}\left(2500 \mathrm{ft}^{3} \mathrm{~s}^{-1} / 2180 \mathrm{ft}^{2}\right)$, and the maximum water velocity is about $2.3 \mathrm{ft} \mathrm{s}^{-1}\left(5000 \mathrm{ft}^{3} \mathrm{~s}^{-1} / 2180 \mathrm{ft}^{2}\right)$. The highest water velocities will 
occur in the main channel of the Des Plaines River (at least during flow events) from which the approach channel and lock chamber are partially isolated (connected only at the confluence of the approach channel with the river channel).

Figure 4. Picture taken during emptying of the navigation chamber at BRLD. Note highly turbulent conditions immediately downstream of the lock and for some distance downstream into the approach channel.

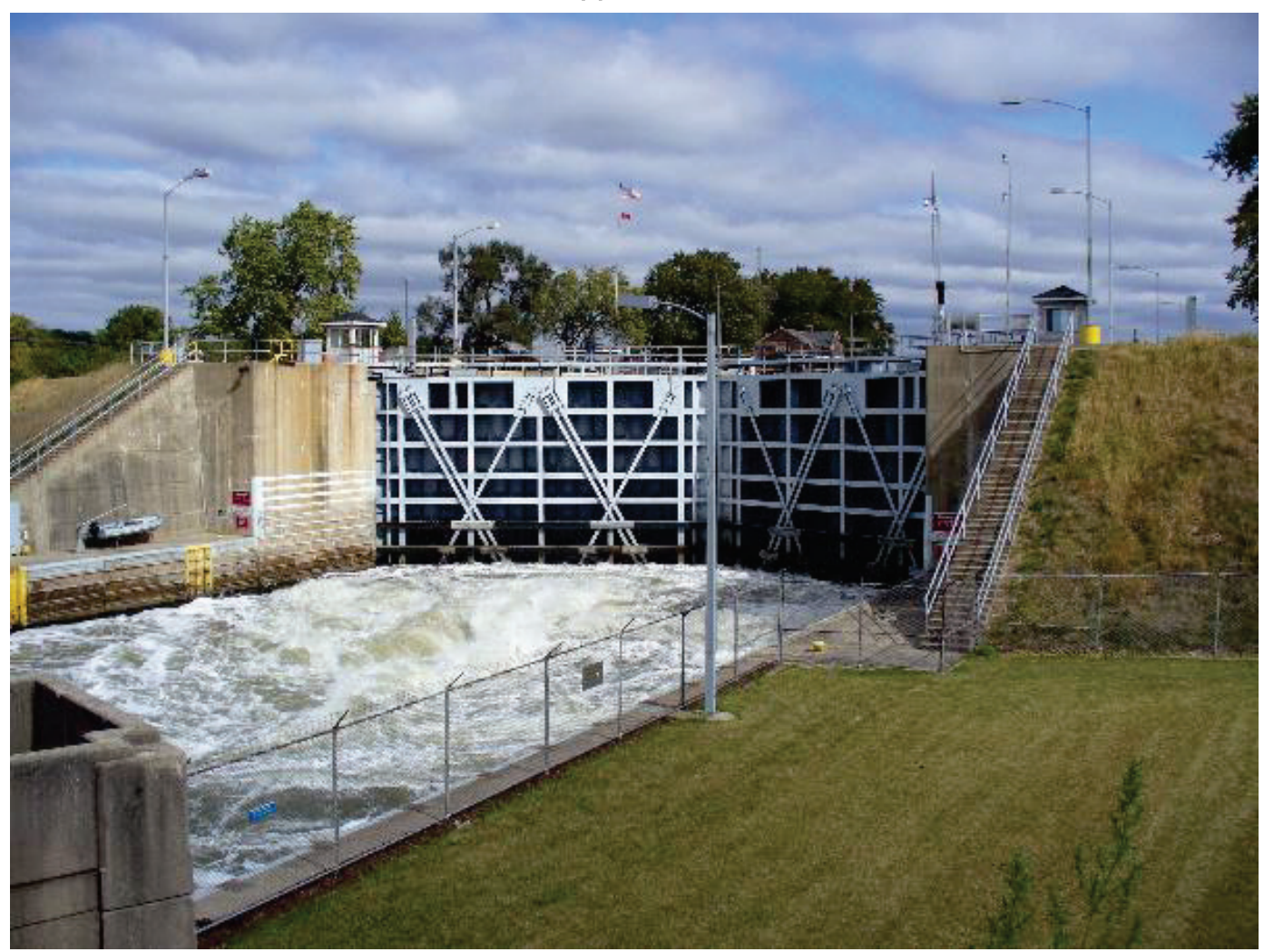




\section{Risk Analysis Associated With the $\mathrm{Co}_{2}$ Barrier}

\subsection{Background}

A risk and feasibility analysis for a $\mathrm{CO}_{2}$ barrier requires knowledge of its size, mode of operation, and location. Unfortunately, a field-scale elevated $\mathrm{CO}_{2}$ barrier does not exist. Therefore, there can be no data on which to substantiate either the feasibility of such a barrier or the risks associated with system design features or system operation. However, attributes of a probable $\mathrm{CO}_{2}$ barrier design can be deduced based on the following sources:

1. laboratory studies describing the characteristics of gas deployment technologies in aquatic systems,

2. general description of water aeration systems,

3. the type of aerating systems used to deliver ozone and $\mathrm{CO}_{2}$ for swimming pool water quality maintenance, and

4. characteristics of the likely deployment site in the Chicago River Sanitary and Ship Canal.

In addition, a Request for Information (RFI) from the Board of Trustees of the University of Illinois, on behalf of the Department of Natural Resources and Environmental Sciences, was obtained that described a prototype-scale test of a full-scale $\mathrm{CO}_{2}$ barrier located within the navigation chamber "to quantify the potential of carbon dioxide (i.e., dissolved $\mathrm{CO}_{2}$ gas) to act as a barrier to fish movement." It seems reasonable to assume that the navigation chamber may serve as test location but that other possible locations may be considered after the completion of the test. Therefore, this report assumes that the final location of the $\mathrm{CO}_{2}$ barrier has not been decided.

The system will likely be scaled similarly to acoustic/bubble barriers located in several places in the world. In addition, the RFI disseminated by the University of Illinois describes a prototype-scale barrier to be tested for effectiveness in the lock chamber. There is no indication that a final system (if one is constructed) will be based on the test system. Current thinking supports the creation of elevated $\mathrm{CO}_{2}$ without the formation of bubble plumes to avoid a supersaturated condition that would wastefully release $\mathrm{CO}_{2}$ to the atmosphere. These design goals are laudable and should be pursued to the maximum extent possible. Unfortunately, the authors 
were unaware of any documents in which such a system is described for review. Therefore, this report can only infer the attributes of such a system based on literature information about bubble formation.

\subsection{Bubble formation}

Bubble formation is a threshold (i.e., non-linear) process that signals the onset of nucleation (formation of a new thermodynamic phase). Nucleation is separated into two categories, homogeneous versus heterogeneous. Homogeneous nucleation occurs in a system without impurities or not under the influence of boundary surfaces. Heterogeneous nucleation occurs at nucleation sites (e.g., impurities) or surfaces in the system. Importantly, homogeneous nucleation occurs much more slowly than heterogeneous nucleation. For example, as champagne connoisseurs can attest, bubbles form slowly in a very smooth, clean glass and much more quickly in a scratched glass with remnant fibers from the drying towel. This distinction between homogeneous versus heterogeneous nucleation is critical in understanding why findings from bench and mesoscale experiments in a laboratory setting may not extrapolate to prototype scale applications in the open field. It may be plausible to create elevated $\mathrm{CO}_{2}$ concentrations without either bubbling or the creation of significant numbers of collateral bubbles because homogeneous nucleation can be expected to dominate under laboratory or controlled settings.

However, in the open field, it has been determined that heterogeneous nucleation will dominate for three reasons:

1. Water pressure field in a lock setting is not constant. During the filling phase of a locking cycle, increasing water depth in the lock will cause an increase in bottom pressure which will ultimately increase the concentration of $\mathrm{CO}_{2}$ that can be dissolved. Conversely, water pressure at the bottom of the water column will decrease during the emptying phase of a lock cycle as water levels are lowered, which will result in an increased rate of formation of $\mathrm{CO}_{2}$ bubbles. The rate of the formation of bubbles will be controlled by a number of factors whose description is outside the general nature of this report. Research indicates that a description of the formation of $\mathrm{CO}_{2}$ bubbles in water treatment plants is a useful source of information (Scardina and Edwards 2001) that would most likely apply to the barrier system.

2. The water pressure field within a lock setting is not uniform, so the potential for bubble formation is also not uniform. Bubble formation 
increases in zones of lower pressure. For example, bubbles form on the mixing paddles in a water treatment plant because the trailing surface of the paddle becomes a localized zone of reduced pressure as it moves (Scardina 2004). The presence and energy level of turbulent structures is a useful visual manifestation of the non-uniformity of the water-pressure field. Turbulence associated with strong gradients in water pressure will be associated with the discharge of the culverts, localized flow at the filling and emptying ports within the lock chamber, at the stern of a moving tow or barge, from the propeller wash of the towboat, and on the trailing (upstream) surface of the towboat's (or other vessel's) propeller.

3. The Des Plaines River is far from an impurity-free system from a bubble formation standpoint. Biotic (e.g., suspended algae) and abiotic (e.g., suspended sediments) and other impurities in the water column will serve as nucleation sites. In addition, the weathered concrete walls of the navigation chamber and filling and emptying system, the rough hulls of barges and towboats, and the bottom of the approach channel will all function as heterogeneous nucleation sites.

For the reasons outlined above, it is not conceivable to create elevated $\mathrm{CO}_{2}$ concentrations without creating a substantial bubble field either directly from a bubbling system, or collaterally from a system that does not use bubbling. Therefore, using the precautionary principle, it is suggested that planners for this system assume that the creation of a bubble field of sufficient magnitude to create a barrier that is fully operational under the above conditions and that all of the direct and indirect negative impacts of a bubbling system are considered. This course of action is recommended until studies are completed that quantify the size and numbers of bubbles that are produced, either directly by a bubbling system or by degassing of dissolved $\mathrm{CO}_{2}$.

Based on these several lines of evidence presented in the previous paragraphs, the system that would create the $\mathrm{CO}_{2}$ barrier would likely have the following attributes:

1. The size (volume) of the zone of effectiveness of the barrier, as long as it blocks the channel, is probably less important than the presence of sharp and persistent $\mathrm{CO}_{2}$ gradients. A more gradual $\mathrm{CO}_{2}$ increase over distance (lower gradient) will be less likely detectable by fish. This makes it more difficult for fish to determine the direction of decreasing $\mathrm{CO}_{2}$ concentration needed to guide them away from the barrier. 
2. It is unlikely that more than a single distinct barrier will be constructed because there would be no repelling advantage to trapping Asian carp between barrier components. An exception might be the construction of a multi- $\mathrm{CO}_{2}$ injector system that begins operation near the navigation chamber and then cascades downstream to "sweep" Asian carp towards the Des Plaines River or into a constructed side channel where Asian carp can be harvested or destroyed.

3. The $\mathrm{CO}_{2}$ bubble plume (for a bubbler) or jet (from venture injector) must extend from the channel margin to the opposite channel margin without gaps or zones of shallow gradients.

4. The bottom of the channel where the barrier is constructed should be relatively flat to prevent gaps from occurring underneath the $\mathrm{CO}_{2}$ bubbler or venture jet. The water column associated with the barrier should be completely mixed (top to bottom and side to side) within the channel to ensure that $\mathrm{CO}_{2}$ levels are adequately maintained in the entire channel cross section.

5. The formation of turbulent cells that could entrain low- $\mathrm{CO}_{2}$ eddies should be avoided. Fish contained in such eddies would not be subjected to elevated $\mathrm{CO}_{2}$ levels until the turbulent cell dissipates. It may be necessary to use a bubbling system that generates two or more sizes of bubbles. Small bubbles (less than $2 \mathrm{~mm}$ diameter) would be used to maximize mass exchange; however, their longer rise time would make such a bubble plume easier to disrupt by water exchange or by mixing (described later). A separate, co-located system could possibly use large bubbles (greater than $2 \mathrm{~mm}$ diameter) with shorter rise times and higher entrained water velocities to maintain the integrity of the bubble plume even when water exchange and mixing occur.

6. The structural parts of the barrier should be armored, reinforced, or hardened to prevent them from being displaced or damaged by anchor drag, keel contact, or prop wash.

7. The $\mathrm{CO}_{2}$ barrier must be able to adjust to changing discharge and water surface elevation to maintain the mentioned attributes (i.e., list numbers 1-5).

8. The barrier system should be redundant in all of its systems, including backup power. The most critical subsystems should be triple-redundant to protect against accident, collisions, vandalism, and power failure.

9. The barrier should be monitored at all times to ensure that the system is maintaining adequately elevated levels of $\mathrm{CO}_{2}$.

10. An area upstream of the barrier and not characterized by $\mathrm{CO}_{2}$ bubbles (bubbles cause false positives) should be monitored with a fishery hydro- 
acoustics system to ensure that the system maintains biological effectiveness.

11. Ideally, a fish repelling system requires a refuge or harvest zone to which fish can be directed, otherwise fish remain in the vicinity of the barrier and have the potential to engage in multiple passage assaults on the system. The efficiency of the barrier system can be increased by reducing the encounter rate of fish with the barrier. In addition, it may be possible to concentrate fish for easier removal from the waterway if they can be kept in one place. 


\section{Risk Categories}

\subsection{Barrier failure analysis}

The following risk analysis considers all possible passages that an Asian carp could potentially use to move upstream through BRLD.

\subsubsection{Spillway}

Fish can potentially pass through the spillway gates of the lock and dam and are known to do so on the Mississippi River (Wilcox et al. 2004). However, there are neither data nor anecdotal information indicating that fish are able to pass upstream through the spillway at BRLD specifically. Useful information about the ability of fish to pass through the BRLD can be obtained from sites on the Mississippi River where fish are thought to move through certain locks and dams, particularly those that have a relatively small elevation difference between the forebay and tailwater. In fact, some of the Mississippi River locks and dams are submerged at higher flows, resulting in a negligible elevation difference between the forebay and tailwater. The Mississippi River locks and dams where fish are not thought to pass have the highest lifts, such as St. Anthony Falls (Lock and Dam 1) where the normal elevation difference is $67 \mathrm{ft}$ (upstream pool at $75^{\circ} \mathrm{ft}$ and downstream pool at $687 \mathrm{ft}$ ), Keokuk Iowa (Lock and Dam 19) where the normal elevation difference is $38 \mathrm{ft}$ (upstream pool at $518 \mathrm{ft}$ and downstream pool at $480 \mathrm{ft}$ ), and Lock and Dam 15 (upstream pool at $561 \mathrm{ft}$ and lower pool at $545 \mathrm{ft}$ ) where the normal elevation difference is $16 \mathrm{ft}$. The lifts of the rest of the Mississippi River Lock and Dams average about $10 \mathrm{ft}$. The normal lift at BRLD is $34 \mathrm{ft}$, similar to the lift of Lock and Dams 19 on the Mississippi River. The minimum recorded lift at BRLD has never been less than $23 \mathrm{ft}$. Therefore, it is probably safe to conclude that no native or ANS will be able to pass upstream through spillway gates at BRLD.

\subsubsection{Lock chamber filling and emptying culverts}

Fish can pass upstream using lock culverts for all or part of their passage. Analysis of lift gate design and operation during emptying and filling at BRLD (described earlier in section 2) suggests that upstream migrating fish could easily enter into the culverts through the discharge ports when water velocities decrease to less than a fish's sustained swimming speed. Water velocity at the discharge ports of the culvert approach zero during the later phases of emptying the lock chamber (as water elevation in the 
lock chamber approaches the tailwater elevation). Fish could enter the lock chamber through the filling ports and later exit through the upstream operational miter gates that are opened when the water levels within the lock chamber and forebay are approximately equal. There is even a possibility that fish could swim the length of the culvert and exit out of the culvert intake to gain access to the forebay of BRLD. Although never observed (to our knowledge no one has ever studied fish movement out of the culvert intakes), it is plausible that water displaced by the tow as it exits would re-enter the lock chamber either through the culvert intake, beside the individual barges, or under the tow. Water flowing into the culvert intake would provide a rheotactic (stimulus provided by moving water) cue to fish to swim upstream through the culvert. Given the possibility (perhaps even the likelihood) of fish movement through the culverts, it is important for the design of the fish barrier to consider fish passing upstream using the culverts either with or without entry into the lock chamber. It should be noted that the RFI from the University of Illinois gave some thought to this eventuality because it mentioned installing the carbonation system within the culverts. Therefore, it is concluded that fish passage through the culverts that are used to empty and fill the lock chamber may be an underestimated, yet important, avenue of fish movement through locks and dams.

\subsubsection{Lock chamber and approach channel}

The most obvious pathway for ANS to pass around BRLD is through the lock chamber during barge and vessel passage. For clarity and brevity, the approach channel and lock chamber risks are described in a single section because they are contiguous. Two physical processes are important to gage the failure potential (i.e., unintended passage of ANS) of the behavioral barrier: water exchange and water mixing. Water exchange results in the mixing of water with elevated $\mathrm{CO}_{2}$ concentrations with water not containing elevated $\mathrm{CO}_{2}$ concentrations. Water exchange can occur at four locations within the approach channel and lock chamber: (1) at the confluence with the Des Plaines River, (2) where the approach channel meets the lock chamber, (3) at the upstream entrance to the lock chamber, and (4) in the lock chamber during filling as water from the forebay passes through the lock culverts. Depending upon the location of the $\mathrm{CO}_{2}$ injectors, water exchange may:

1. deteriorate the repelling effect by reducing the $\mathrm{CO}_{2}$ concentration within the barrier, 
2. reduce the gradient of $\mathrm{CO}_{2}$ concentration at the barrier boundaries (i.e., reducing barrier detectability), and

3. compromise the integrity of the barrier boundary. That is, a boundary characterized by a coherent and relatively consistent high gradient of $\mathrm{CO}_{2}$ is replaced by either a low gradient or a turbulent boundary containing pockets of water having either high or low $\mathrm{CO}_{2}$ concentrations. Fish within these pockets will be surrounded by water of equal $\mathrm{CO}_{2}$ concentration; and therefore, they will not be able to sense the direction in which they should swim to avoid elevated $\mathrm{CO}_{2}$ exposure.

Water mixing reduces dissolved $\mathrm{CO}_{2}$ concentrations of the barrier by increasing surficial contact with the atmosphere. There are four sources of mixing in the approach channel and lock chamber: (1) in the upstream end of the approach channel where lock chamber water is released through the discharge ports during emptying, (2) from the turbulence created by high water velocities associated with the movement of displaced water caused by movement of a vessel, (3) from prop wash from the vessel, and (4) in the lock chamber as filling water enters through the lock ports (lock filling causes both water exchange and mixing). Increased contact with the atmosphere increases the rate at which dissolved $\mathrm{CO}_{2}$ degasses and will require a corresponding increase in carbonation to maintain the target $\mathrm{CO}_{2}$ concentration. The other effects of increased mixing on barrier performance are approximately equal to those described in the previous paragraph. Importantly, the lock chamber is an enclosed space during operation so that $\mathrm{CO}_{2}$ degassed by water mixing may accumulate within the lock chamber.

\subsubsection{Summary of effects}

Data on the configuration of the spillway and the elevation differences between the forebay and tailwater indicate that the probability of upstream fish passage through the spillway is negligible. An analysis of the configuration of the BRLD culvert system used to empty and fill the lock chamber indicates that upstream passage of fish is likely through all or part of the system. Analysis of the approach chamber and lock chamber indicates that upstream fish passage is likely. Movement of Asian carp through both the culverts, the approach channel, and lock chamber should be considered during barrier design. Without the presence of a navigation tow, the approach channel appears to be a low-energy hydraulic environment in contrast to the Des Plaines River downstream of the spillway. An unexpected finding is the intermittent occurrence of highenergy water exchange and mixing events associated with lockage of 
vessels through the BRLD and emptying of the lock chamber. The design and operation of the $\mathrm{CO}_{2}$ barrier must ensure the efficiency of gas transfer and the integrity of the zone of elevated $\mathrm{CO}_{2}$. Therefore, it will be important to monitor the operational effectiveness of a $\mathrm{CO}_{2}$ barrier under this high-energy, low-frequency event to ensure that the barrier can be effective under the full array of conditions anticipated at BRLD.

\subsection{Risks to human health and survival}

Risks to human health and survival can be broadly separated into two parts: drowning and asphyxiation in an enclosed space when atmospheric $\mathrm{O}_{2}$ is displaced by $\mathrm{CO}_{2}$.

\subsection{1 $\mathrm{CO}_{2}$ intoxication, loss of consciousness, and asphyxiation}

As a gas, $\mathrm{CO}_{2}$ is colorless, odorless, heavier than air, and not dangerous in natural atmospheric concentrations $(0.3 \%-0.4 \%)$. However, because it is heavier than air, it can fill enclosed spaces and cause death by asphyxiation by displacing atmospheric $\mathrm{O}_{2}$, as is known by those in the swimming pool industry where $\mathrm{CO}_{2}$ is commonly used as part of pool water treatment (Profession Pool Operators of America 2010). Enclosed spaces of concern associated with a $\mathrm{CO}_{2}$ barrier are the closed lock chamber, any sheds in which parts of the barrier may be housed, and enclosed storage areas where $\mathrm{CO}_{2}$ gas may be stored. A closed lock chamber is the condition where both sets of lock miter gates are closed, and the chamber itself has the potential to become an enclosed space that will fill from the bottom up with $\mathrm{CO}_{2}$. The accumulation of $\mathrm{CO}_{2}$ in the lock chamber is a critical issue if the elevated $\mathrm{CO}_{2}$ barrier is located in the lock chamber or in the lock culverts. The filling cycle of lock operations takes 19 minutes. According to the Center for Disease Control and Prevention (CDC 2014), a concentration of $50,000 \mathrm{ppm}(5 \%)$ of $\mathrm{CO}_{2}$ for 30 minutes results in intoxication; a few minutes exposure to $70,000 \mathrm{ppm}$ to $100,000 \mathrm{ppm}(7 \%-10 \%)$ results in unconsciousness; and a 5 minute. exposure to 90,000 ppm (9\%) is lethal. An intoxicated or unconsciousness boat operator can damage a vessel or cause the death or injury of others in the lock chamber. An intoxicated or unconscious crew member can injure themselves, fall into the water and drown, or create conditions that result in the death or injury of others. Although a routine filling cycle takes 19 minutes, it will remain important to conduct safety testing for much longer time periods to include scenarios where equipment breakage or navigation traffic congestion produce filling times much greater than 19 minutes. 
It is important to consider two long-term effects of elevated $\mathrm{CO}_{2}$ in addition to short-term cognitive impairment and unconsciousness described above (Rice 2004). Medical experience at natural disasters and industrial accidents indicates that $\mathrm{CO}_{2}$ has a continuum of toxic effects depending upon the duration and concentration of exposure interacting with individual variables such as age, health, physiological condition, activity level, and related variables. Experience with survivors of high-level $\mathrm{CO}_{2}$ exposures indicates that some exposure effects may linger within individuals. Rice (2004) summarizes a suite of effects of long-term exposure of 3-42 days to low levels of elevated atmospheric $\mathrm{CO}_{2}(0.85 \%-3 \%)$. Relatively short-term chronic exposure (3-8 days) to low levels of elevated $\mathrm{CO}_{2}(1.2 \%-3 \%)$ resulted in increased cerebral blood flow, increased blood pressure, and significant cognitive impairment. Long-term chronic exposure (20-42 days) to low levels of elevated $\mathrm{CO}_{2}(0.85 \%-2.0 \%)$ included moderate to slight increased lung dead-space volume; significant decrease in bone formation biomarkers (with slight increase in bone reabsorption); increase in urine volume and sodium, potassium, and chloride excretion (slight increases in hematocrit [ratio of the volume of red blood cells to the total volume of blood], red blood count, and hemoglobin); and cognitive impairment. The danger of long-term chronic effects of exposure to low-levels of elevated $\mathrm{CO}_{2}$ should be assessed for individuals working near the barrier or exposed during frequent transits.

Because $\mathrm{CO}_{2}$ is heavier than air, it will fill an enclosed space from the bottom to the top. Individuals in small craft, because of their proximity to the water surface, may be particularly susceptible to elevated atmospheric $\mathrm{CO}_{2}$ concentrations. To understand the danger to human safety, one must determine the rate of $\mathrm{CO}_{2}$ degassing associated with operation of the barrier. The degassing rate can be used to help calculate the maximum thickness of the elevated $\mathrm{CO}_{2}$ layer within the lock chamber during an emptying or filling cycle. Worst-case conditions should be analyzed to determine the thickness of the elevated $\mathrm{CO}_{2}$ concentrations. For example, the degassing rate should be greatest under warm water conditions when the amount of $\mathrm{CO}_{2}$ that can be dissolved in water decreases. The degassing rate should be applied to the longest filling or emptying cycle that has occurred, or that could occur, under extreme conditions (e.g., equipment malfunction). Note that the RFI from the Board of Trustees of the University of Illinois requires monitoring of dissolved $\mathrm{CO}_{2}$ in the lock chamber. It is strongly recommended that atmospheric $\mathrm{CO}_{2}$ monitors that are connected to an alarm system are installed to ensure human safety. In 
the event that there is even the slightest chance that elevated $\mathrm{CO}_{2}$ is a human safety issue, it is recommend that a $\mathrm{CO}_{2}$ venting system for the navigation lock, including the deck above and the downstream deck below the navigation lock (and any other nearby enclosed spaces), that operates when the downstream lock gates are closed is installed. The venting systems should activate if atmospheric $\mathrm{CO}_{2}$ concentrations reach a predetermined danger threshold or be in continuous use as a prevention measure. In addition, operational conditions in which the lock is kept at the tailwater elevation with the downstream miter gates closed should be avoided. Also, gaseous $\mathrm{CO}_{2}$ will infiltrate and fill any low lying spaces. For example, an empty hopper barge, open hatches, or open doors in a vessel will serve as entryways for $\mathrm{CO}_{2}$. Consequently, crew may be in danger of $\mathrm{CO}_{2}$ asphyxiation even after a vessel has exited the navigation chamber. These human safety issues associated with elevated atmospheric concentrations exist and are not based on speculation. Barrier design, testing, monitoring, maintenance, and operation must consider these safety issues concerning $\mathrm{CO}_{2}$ use at BRLD or at any other lock system.

It is important to note that this research is based with analysis of incomplete information; therefore, the list of risks to human health and safety may not be exhaustive. Potential risks to human health and safety should be reevaluated prior to operation of the system and once the design of the barrier is complete. After installation, a period of testing and monitoring should be implemented and documented to ensure the accuracy and completeness of the human health and safety analysis.

\subsubsection{Vessel sinking and human drowning}

Archimedes' principle teaches that the force of buoyancy is equal and opposite to the weight of the displaced fluid. The injection of bubbles in water reduces the weight of the displaced fluid and, therefore, must reduce the buoyancy force supporting a floating vessel or human body. According to Archimedes' principle, a vessel in a bubble plume must sit lower in the water column because of the reduced buoyancy of water that has been injected with $\mathrm{CO}_{2}$ bubbles or any other gas (Adams 2002). Similarly, a person who falls or swims into a bubble plume is at a much greater risk of drowning, even if wearing a life vest. However, estimating buoyancy reduction from a bubble plume is surprisingly complicated; and research into drowning potential in aeration pits yields conflicting results. The buoyancy reduction caused by a bubble plume depends on; 
1. the amount of water displaced by the bubbles in the bubble plume integrated over the depth of the water with consideration that bubbles expand in volume as they rise,

2. the momentum of the water entrained by the rising bubble plume impacting the floating body or vessel,

3. the drag forces of air-entrained water as it rises around the floating body or vessel,

4. the position of a vessel in the bubble plume, and

5. the buoyancy effect of bubbles that infiltrate into the clothing of a person floating in the water.

Importantly, factors 2 and 3 can be either positive or negative. That is, a person or vessel directly under a bubble plume will be buoyed by momentum and drag; but a person or vessel outside of the center of the bubble plume may be entrained downward as mass conservation (e.g., a bubble plume in the center of a lock chamber will likely cause upward momentum and drag forces, but downward drag at the lock walls) causes the water entrained by the bubble plume to plunge downward. Model studies (Hueschen 2010) indicate that the swamping effect of a bubble plume is greater if a vessel is partially located in the plume. The increased buoyancy of the part of the vessel outside of the bubble plume tips the vessel lower into the bubble plume than if the vessel is located entirely inside of the plume. Vessel sinking results when water swamps the lowest part of the vessel located in the bubble plume. Sinking of part of a tow or a smaller vessel will have substantial impacts on navigation through the BRLD because of the amount of time required to raise a sunken vessel and to conduct search and rescue operations for vessel crew and passengers.

Insufficient information was available to calculate the effects of reduced buoyancy on either vessel sinking or human drowning potential because the attributes of the design of the $\mathrm{CO}_{2}$ injection system are unknown. Therefore, we recommend conducting tests measuring buoyancy reduction caused by $\mathrm{CO}_{2}$ bubbles:

1. for different sizes and densities of bubbles,

2. under a full range of operational conditions expected during routine operation, maintenance, and equipment testing,

3. under extreme conditions associated with overloaded boats or unusual boat wakes, 
4. using a representative array of vessel types and sizes expected to use the lock,

5. using extreme types of vessels (e.g., an overloaded fishing boat), and

6. using tethered human test subjects (or human dummies) of a range of different sizes and buoyancies, wearing a range of typical clothing types, and with/without personal floatation devices.

Additional tests should determine if $\mathrm{CO}_{2}$ generated by the barrier will infiltrate into a vessel (e.g., through hatches or doors into the lower decks) or barge (e.g., into a hopper barge) and settle into enclosed spaces. Trapped pockets of elevated $\mathrm{CO}_{2}$ could create safety issues well after a vessel has left the lock. We recommend that sensors used for testing record $\mathrm{CO}_{2}$ levels over a long duration, examining time, course, and cumulative exposure rather than just peak concentration.

\subsection{Risks to the environment}

\subsubsection{General}

As explained in the companion literature review (Nestler 2014), dissolved $\mathrm{CO}_{2}$ chemically reacts with water to form a weak acid called carbonic acid. Concomitantly, elevated dissolved $\mathrm{CO}_{2}$ will reduce $\mathrm{pH}$ (Schindler 1988), which has a set of effects different than those associated only with elevated dissolved $\mathrm{CO}_{2}$. The duality of the impacts from a $\mathrm{CO}_{2}$ barrier is further complicated by the buffering capacity (measured as total alkalinity) of the water around the barrier. Water with a high total alkalinity will tend to reduce and localize any effects of low $\mathrm{pH}$ because the bicarbonate buffer system will reduce the extent of $\mathrm{pH}$ shifts and limit the spatial range of low $\mathrm{pH}$. In contrast, water of low alkalinity will exhibit a greater $\mathrm{pH}$ shift and a larger spatial range. Alkalinity values of 20-200 parts per million (ppm based on $\mathrm{mg} / \mathrm{L} \mathrm{CaCO}_{3}$ ) are common in freshwater ecosystems. Alkalinity levels below $10 \mathrm{ppm}$ indicate poorly buffered streams that are likely to suffer the effects of low $\mathrm{pH}$ caused by elevated $\mathrm{CO}_{2}$ levels. Stream alkalinity values are a reflection of the watershed geology (i.e., the dominant types of rock in the watershed) and typically do not change substantially over time under natural conditions. Alkalinity measurements from grab samples at BRLD from 8 June 1994 to 1 November 1994 had a mean of 133 ppm with a range of 123-163 ppm (USACE 1996). The medium alkalinity of water at the BRLD suggests that risks to the environment should be localized and minimal. However, for completeness the typical effects of low $\mathrm{pH}$ on different resource categories is described below. 


\subsubsection{Effects on plants}

As known by aquarium hobbyists, plants remove $\mathrm{CO}_{2}$ at a rate much greater than the rate at which atmospheric $\mathrm{CO}_{2}$ equilibrates with aqueous $\mathrm{CO}_{2}$ in a quiescent environment (Morin 2014). Logically, it is reasonable to speculate that elevated $\mathrm{CO}_{2}$ concentrations in areas sheltered from wind and wave action (much like the approach channel and immediately upstream of the lock chamber) may exhibit localized luxuriant growth of phytoplankton and aquatic vegetation, if light or nutrients are not limiting, particularly during the growing season when higher water temperatures reduce the amount of $\mathrm{CO}_{2}$ that can be dissolved in water (Hargrave et al. 2009). However, given the anticipated localized effects of the $\mathrm{CO}_{2}$ barrier, it seems unlikely that enhanced macrophyte growth will create nuisance abundances.

\subsubsection{Effects on fishes and shell-building organisms}

Elevated atmospheric levels of $\mathrm{CO}_{2}$ are contributing to global warming but also pass through the air-water interface to increasingly acidify the world's oceans. Much of the increase in hydrogen ions is absorbed by the carbonate buffer system so that the net effect on ocean $\mathrm{pH}$ is only a decrease of about a $0.1 \mathrm{pH}$ unit (Jacobson 2005). However, the increased availability of the hydrogen ion effectively reduces the concentration of calcium carbonate available to shell-building marine organisms (Feely et al. 2004). Orr et al. (2005) documented that this small pH change reduces calcification rates in shell-building organisms, such as corals, mussels, and arthropods, particularly if combined with additional stressors like increased water temperature. The literature on impacts of elevated $\mathrm{CO}_{2}$ on marine organisms is extensive and outside the scope of this report. The interested reader can find entry points to the extensive literature for corals (Coehn and Holcom 2009), fishes (Devine et al. 2012; Domenici et al. 2012), and mollusks and foraminifera (Fabry et al. 2008).

The $\mathrm{pH}$ range in natural freshwater is much broader $\left(5^{-8}\right)$ than in marine systems (7.5-8.4). However, the diurnal change in $\mathrm{pH}$ of freshwater (from the uptake of aqueous $\mathrm{CO}_{2}$ during photosynthesis and production of $\mathrm{CO}_{2}$ during respiration) can be substantial depending upon alkalinity (buffering capacity). In contrast, the diurnal range of $\mathrm{pH}$ in seawater is much more limited because the carbonate buffer system has a much greater role than in freshwater ecosystems. In freshwater systems, sub-lethal effects of $\mathrm{pH}$ changes from 7 to $5^{-6}$ have been documented for freshwater snails (Ewald 
et al. 2009). In contrast, under laboratory conditions, the freshwater fingernail clam (Musculium partumeium) exhibited better growth and survival in a $\mathrm{pH}$ of 5.0 (the $\mathrm{pH}$ in the system from which they were collected) compared to a pH of 7.0 (Hornbach and Childers 1987). Less well documented, low $\mathrm{pH}$ can also increase the bioaccumulation, toxicity, and solubility of metals in freshwater, particularly aluminum, but possibly for mercury and lead for macroinvertebrates (Wren and Stephenson 1991), birds, and mammals (Scheuhammer 1991).

The literature documents a large number of effects of elevated $\mathrm{CO}_{2}$ and reduced $\mathrm{pH}$ on fish, but this report will not review this for two reasons. First, many of the effects of increased dissolved $\mathrm{CO}_{2}$ and decreased $\mathrm{pH}$ are described in the companion literature review (Nestler 2014). Second, the purpose of the behavioral barrier is to repel ANS fish; therefore, it is expected that untargeted fish species may experience physiological, reproductive, and behavioral effects from its use.

\subsection{Risks to infrastructure}

The $\mathrm{pH}$ effects of elevated $\mathrm{CO}_{2}$ from the behavioral barrier will mimic some of the effects of acid rain within the behavioral barrier footprint. We can discount most of the impacts because the elevated $\mathrm{CO}_{2}$ concentrations will be restricted to the aqueous phase and minimally affect the surrounding landscape. However, it is important to recognize that increased acidity can affect the corrosion rates of many elements (Driscoll et al. 2001) and complex materials such as concrete. These materials are composed of several calcium-rich phases that are known to carbonate or dissolve in $\mathrm{CO}_{2}$-containing environments or other construction materials containing aluminum, iron, or possibly other metals subject to acid-based corrosion (Colls 2003).

In the peer-review literature, there is relatively little information on the effects of reduced $\mathrm{pH}$ and elevated $\mathrm{CO}_{2}$ levels on submerged concrete structural integrity and deterioration. The bulk of the information used in our report comes from Lagerblad (2006) and Research Designs and Standards Organization (RDSO) Lucknow (2008). We recommend that the reader consult these sources for more detailed information. Understanding the effects of reduced $\mathrm{pH}$ on concrete requires a brief description of the chemical changes involved in the manufacture of cement and the deterioration (weathering) of concrete in humid or aquatic settings. Cementitious materials such as concrete are rich in calcium because calcined limestone 
and other minerals are used for the production of conventional portland cements. When combined with water, hydration reactions result in a microstructure that contains various forms of hydrated calcium silicates, calcium sulfoaluminates, calcium hydroxide, and a high ionic strength in solution (pore solution that is rich in calcium, potassium, sodium, and sulfate among other species). Over time, hardened concrete will bind with $\mathrm{CO}_{2}$ in the reverse process of calcination, called carbonation. This process is generally attributed to the reaction between $\mathrm{CO}_{2}$ and the calcium hydroxide phase present in portland cement paste to form calcium carbonate. In atmospheric conditions, carbonate occurs at a rate of approximately $1 \mathrm{~mm} /$ year in typical concrete. In submerged conditions with elevated $\mathrm{CO}_{2}$ concentrations (i.e., above $200-400 \mathrm{ppm}$ ), the potential carbonation rates are unknown. Obviously, the deterioration of concrete to its component materials jeopardizes the integrity of the structure.

The rate of carbonation is determined by a complex set of processes and simplifying assumptions must be made to give an overview. First, carbonation requires an external moisture source within which atmospheric $\mathrm{CO}_{2}$ can dissolve to form carbonic acid. Carbonation will not occur in the absence of moisture. Typically, a relative humidity level of $50 \%-70 \%$ is necessary for carbonation to occur. In terrestrial applications and starting with an unfractured surface, carbonation is a surface process that slows as carbonated cement forms a shell that partially protects deeper parts of the monolith. Fractures of the concrete will allow dissolved $\mathrm{CO}_{2}$ entry to the interior of the concrete monolith and will speed the deterioration of the cement paste. Pieces of concrete that spall off (e.g., from frost or freezing) will expose new surfaces and consequently result in higher rates of carbonation. In addition to the surface integrity of the concrete, additional factors that determine the rate of carbonation include $\mathrm{CO}_{2}$ concentration, size, and geometry of concrete porosity, the degree of water saturation (in terrestrial settings), the type of cement/binder, temperature, and other factors dependent upon the type of concrete used and its application in a specific setting. In normal aqueous applications, the rate of carbonation is reduced because the capillary system of the concrete is filled with water so that the rate of gas transfer, and hence the rate of carbonation, is reduced. In some reduced soils (i.e., having low oxidation-reduction potential), the decay of organic matter may substantially increase $\mathrm{CO}_{2}$ concentration; however, the speed of diffusion of $\mathrm{CO}_{2}$ through the concrete is slow (following Fick's second law). 
No specific information on the effects of extremely elevated levels of aqueous $\mathrm{CO}_{2}$ on submerged concrete deterioration could be found while compiling information in this report. However, in terrestrial settings, the rate of carbonation in urban and interior environments with higher levels of $\mathrm{CO}_{2}$ concentration is measurably greater than in non-urban areas, indicating that even relatively small increases in $\mathrm{CO}_{2}$ concentration may have substantial effects on the structural integrity of submerged concrete. It is reasonable to assume that $\mathrm{CO}_{2}$ levels hundreds or thousands of times higher than normal and associated with highly turbulent hydraulic transport (instead of Fickian diffusion) may have a substantial and serious effect on the life cycle and integrity of a concrete structure. However, this conclusion is speculative and based on extrapolations from knowledge of generalized concrete chemistry and the carbonation dynamics of concrete primarily in terrestrial settings. The complexity of concrete carbonation and its dependence on numerous factors means that projections of impact caused by the $\mathrm{CO}_{2}$ barrier should, to a large extent, rely on laboratory data, empirical data, and measurements made either on concrete samples or on actual concrete structures.

The structural consequences associated with carbonation are primarily related to the shift in pore solution $\mathrm{pH}$ that occurs following the corrosion process. As calcium hydroxide (a solid phase that buffers the pore solution to a $\mathrm{pH}$ greater than 12.5) is consumed and calcium carbonate forms, the $\mathrm{pH}$ of the pore solution reduces from $13-13.5$ to 9-10. This reduction in $\mathrm{pH}$ will cause reinforcing steel, which is passivated and protected from corrosion, to depassivate, resulting in a potential for the initiation of corrosion. While it is generally simple to predict service lives associated with carbonation-induced corrosion in structures with an atmospheric exposure (i.e., common knowledge of anticipated carbonation rates), it is unknown how rapid carbonation will occur in submerged concrete structures that are exposed to high concentrations of $\mathrm{CO}_{2}$. The potential for impacts of elevated $\mathrm{CO}_{2}$ concentrations associated with the behavioral barrier should be evaluated by an expert in submerged concrete deterioration (e.g., at the Geotechnical and Structures Laboratory of the U.S. Army Engineer Research and Development Center).

The type of aggregate used to construct BRLD will also affect the rate of submerged concrete deterioration in the presence of elevated aqueous $\mathrm{CO}_{2}$ concentrations. Siliceous aggregates (e.g., granite, chert, and basalt) are highly resistant to deterioration when exposed to high concentrations of 
$\mathrm{CO}_{2}$ in aqueous environments. However, limestone aggregates, which are commonly used in many USACE concrete structures, are vulnerable to rapid dissolution when exposed to high concentrations of $\mathrm{CO}_{2}$. This susceptibility of limestone aggregates to dissolution will largely depend on the carbonate alkalinity of the local water and the effect of the barrier $\mathrm{CO}_{2}$ concentration on water alkalinity.

The final design of the behavioral barrier has not been determined, so impacts of elevated $\mathrm{CO}_{2}$ concentrations must be considered as the barrier is designed for all concrete surfaces, including the lock chamber surface, culverts (including the intakes, discharge ports, and filling ports), and concrete surfaces associated with the miter gates. Deteriorated concrete associated with culverts may be particularly difficult to repair because of their location internal to the structure.

In addition to the deterioration of concrete, elevated carbonic acid concentrations increase the oxidation (rust) rate of rebar; and the resulting expansion during corrosion produces stresses within the concrete that may exceed the tensile strength of the concrete. The expansion of rebar may result in cracks, spalling (i.e., breaking, flaking, or pitting), and delamination (concrete surface detaches over an air filled void-often along the plane of the rebar layer) (George and Nesic 2007).

Laboratory studies can measure the increased rate of submerged concrete deterioration caused by exposure to elevated concentrations of aqueous $\mathrm{CO}_{2}$. The measured carbonation rate can be used to estimate the time at which the carbonation front will reach the concrete cover depth over embedded reinforcing steel. The rate can be compared to the anticipated service life of the barrier structure to determine the severity of the problem and need for intervention. Several options are available to mitigate the effects of elevated aqueous $\mathrm{CO}_{2}$. First, a higher-quality concrete with lower permeability can be used. Use of silica fume and a low water-to-cement ratio can achieve this reduction in permeability. A variety of coating types are also available that form a physical barrier to the infiltration of $\mathrm{CO}_{2}$. However, these coatings will likely need to be reapplied as they deteriorate. It is recommended to consult a concrete expert for application needs and guidance. 


\subsection{Mitigating effects of elevated $\mathrm{CO}_{2}$ through aeration}

It is likely that $\mathrm{pH}$ changes caused by the $\mathrm{CO}_{2}$ behavioral barrier will have only a localized effect on aquatic biota. If elevated $\mathrm{CO}_{2}$ generated by a behavioral barrier is later found to be a problem, then it can likely be reduced by reversing the process that produced the high concentration. For example, both increased water mixing and aeration will increase the rate that $\mathrm{CO}_{2}$ degasses into the atmosphere and thus return treated water to equilibrium with atmospheric $\mathrm{CO}_{2}$. A carbonation system can create elevated $\mathrm{CO}_{2}$ as a barrier and an associated aeration system outside of the treatment zone can restore $\mathrm{CO}_{2}$ concentrations closer to natural levels or help prevent the accumulation of dangerous levels of $\mathrm{CO}_{2}$ within the lock chamber or other enclosed space. A large number of companies that specialize in reservoir aeration and destratification can be consulted to design or construct a system that limits the spatial extent of the elevated $\mathrm{CO}_{2}$ generated by the barrier. 


\section{Barrier Feasibility}

\subsection{Biological feasibility}

The power industry has used, with mixed success, structural and behavioral fish barriers that minimize entry of fish into areas that could injure or kill them. As part of the development of fish barriers to prevent entrainment of fish into a pump turbine hydropower system, Nestler et al. (1995) proposed a protocol to assess the feasibility of designing an effective barrier based on fish size distribution, fish seasonal abundance, water flow direction, water velocity distribution, and spatial scale of a potential application.

\subsubsection{Fish size distribution}

Both structural and behavioral barriers usually have an optimum efficiency for a restricted size range of fish. For example, a wedge wire screen may work best for larger fish, compared to smaller fish, because they can be physically excluded with a reduced danger of impingement (where water velocity presses the fish against the screen, leading to eventual suffocation or exhaustion). A larger gap also minimizes clogging from waterborne debris. In the case of an electrical barrier, the field lines must be close enough together to simultaneously contact both ends of a fish for it to be subjected to the current. Therefore, larger fish are more susceptible to electrical barriers than smaller fish. The size range of Asian carp that must be repelled has not been studied but presumably includes any life stages that could either swim upstream or be transported upstream in the wake of a tow (or other vessel type) or in the small-scale hydraulics associated with the operation of BRLD, and the movement of a tow through the approach channel and lock chamber as described earlier in this report. The greatest risk of invasion would be associated with the largest size individuals because they are the strongest swimmers. However, it seems plausible that all life stages of Asian carp should be considered for the $\mathrm{CO}_{2}$ barrier because of the presence of small-scale reversing currents associated with tow movement and navigation operation that could passively transport early life stages upstream.

The literature review conducted in the companion report did not indicate a fish-size effect of the elevated $\mathrm{CO}_{2}$. If substantiated by further research, this finding is important because it suggests that elevated $\mathrm{CO}_{2}$ can be used 
to repel all size classes of Asian carp capable of swimming against the downstream currents at BRLD. The effects of $\mathrm{CO}_{2}$ on sub-juvenile life stages are presently unknown. If the barrier is designed to effectively carbonate reversing currents, then it appears that elevated $\mathrm{CO}_{2}$ concentration is a feasible stimulus with substantial potential for managing the distribution of Asian carp.

\subsubsection{Fish seasonal abundance}

Many fishes exhibit pronounced seasonal distribution patterns associated with migration or life history characteristics. Therefore, fish barriers must often be deployed or operated for specific time periods when target species occur at increased densities. Although much of the life history of Asian carp remains to be studied, it appears from the limited data available that the $\mathrm{CO}_{2}$ barrier should be operated year-round at BRLD. This constraint means that project testing, retrofitting, and maintenance and barrier maintenance must be conducted in a way that does not inadvertently allow for the passage of Asian carp. This adds another layer of complexity to an already complex suite of activities associated with project operation, particularly during periods of heavy lock usage.

\subsection{Site feasibility}

\subsubsection{Water-flow magnitude and direction}

The direction of bulk water flow is a primary constraint on the efficiency of barrier technology. Water intakes and pumped storage hydropower projects (during the pumping phase of operation) entrain fish and other aquatic biota towards the project, which can make the design of the barrier more difficult. For example, a barrier technology that temporarily stuns or disables a fish in some way will simply passively transport fish towards the project along with the flow. However, flow away from the project will transport a stunned or disabled fish downstream of the project. Notably, the behavioral barrier will be designed to repel upstream-migrating fish so that fish that are rendered unable to swim will generally be swept downstream.

Most fish protection systems common at pumped storage hydropower industry and at water intakes have to work in very high-flow environments. For example, the barrier that reduces entry of fish into the powerhouse at the Richard B. Russell Hydropower Dam during full pump storage operation must be able to effectively repel fish in an intake plume of about 
$26,000 \mathrm{ft}^{3} \mathrm{~s}^{-1}$ with a peak velocity of about $6 \mathrm{fps}$ at the trash racks. As described earlier in this report, the cross-sectionally averaged water velocity immediately downstream of the discharge ports during a 15 minute emptying cycle at BRLD is about $1.1 \mathrm{fps}$ with an approximate peak of about 2.3 fps. Compared to USACE non-navigation reservoir projects (many water velocities are over $6 \mathrm{fps}$ ), this is a relatively benign hydraulic environment. The highest water velocities will occur in the main channel of the Des Plaines River (at least during flow events) from which the approach channel and lock chamber are partially isolated (connected only at the confluence of the approach channel with the river channel). The flows associated with lock chamber emptying occur only intermittently as tows arrive at BRLD. Considerations of flow magnitude and flow direction suggest that a behavioral barrier located in the lock chamber or approach channel is feasible.

\subsubsection{Water velocity distribution}

While the bulk water flow is in the downstream direction, it is important to note that short term project operations such as opening and closing of the miter gates and filling and emptying the lock chamber may create smallscale reversing currents that could move a passive object in the upstream direction. While likely not a large part of project operation, it is important to acknowledge the possibility of these reversing flow patterns. The movement of barges and towboats out of the lock chamber and into the approach channel will create water currents in the upstream direction associated with water displacement of the moving barges. The prop wash from a towboat pushing a tow in the downstream direction has the same effect. In addition, barge fleeting activities (i.e., temporary storage of barges and their assembly and disassembly into tows) may also create complex small-scale hydraulic patterns that may move passive objects upstream. It is apparent that there is a number of relatively small-scale, but high-energy reversing currents that are possible in the lock chamber and approach channel that should be considered during behavioral barrier design.

\subsubsection{Spatial scale of application}

The scale of an application must also be a consideration. Large scale applications characterized by high-velocity flows are more difficult to protect than small sites with relatively lower velocities. The BRLD lock chamber is only $110 \mathrm{ft} \mathrm{W} \times 600 \mathrm{ft} \mathrm{L}$ with the highest instantaneous crosssectional water velocity of about $2.3 \mathrm{fps}$, which by hydropower facility 
standards is a relatively small site and low energy hydraulic environment. The BRLD appears to be a feasible site for the installation of a behavioral barrier because of the small site scale and low energy flow patterns.

\subsubsection{Availability of support facilities}

Experience with the behavioral barrier at the Richard B. Russell Dam indicates that system problems and failures tend to happen at the least opportune times, such as in high rainfall events (from severe storms), power outages, and project outage. For reasons unknown, they seem to occur disproportionately during holidays. For example, at Richard B. Russell Dam, a floating log collided and disabled one of the acoustic transducers used to generate a repelling acoustic field. Fortunately, onsite personal were able to assess the damage to the system and determine that sufficient redundancy was built in so that project operation did not have to be stopped during repairs. Therefore, successful long-term operation of the barrier will require that support staff be available for repair and other non-routine activities. The presence of the barrier at a functioning USACE project provides a source of support for short-term emergency actions. This is an important element of feasibility.

\subsubsection{Other site characteristics}

From the aerial pictures, it appears that there is ample room for redundancy of critical system components. It will be important to have backups for power (preferably a generator system in case of blackout); the $\mathrm{CO}_{2}$ source; the injection system; and any other system components that may fail, be damaged, or are susceptible to off-site events such as blackouts, storms, or transportation system failure.

The most significant spatial feature of BRLD is the elevation difference between the forebay and tailwater. The elevation difference is sufficient to likely preclude upstream passage through the spillway where it would be difficult, if not impossible, to create a barrier. The approach chamber and lock chamber are much better candidates because of their limited crosssectional area and relatively reduced velocities as compared to those that could be expected at high flows through the spillway. While challenges remain to be solved, the spatial configuration of BRLD is generally conducive to the installation of a fish barrier. 


\subsubsection{Risks to the project}

There is not an existing $\mathrm{CO}_{2}$ barrier that can be referenced to help understand the likely impacts on the physical plant of the BRLD. Therefore, any direct impacts must be speculative, even though they are based on solid scientific principles. It appears that elevated $\mathrm{CO}_{2}$ can have a significant impact on the carbonation rate (corrosion) of concrete and the corrosion of exposed rebar. However, the many factors that are involved makes accurate prediction of impact nearly impossible. In addition, elevated $\mathrm{CO}_{2}$ can increase the solubility of some metals common in construction (e.g., aluminum, steel, and possibly copper) so that corrosion issues may occur. The testing of $\mathrm{CO}_{2}$ barrier effectiveness to prevent the passage of fish should also include studies to assess the effects of the barrier on the physical plant of BRLD. These studies can be performed during effectiveness testing of the barrier because the effects will likely occur at a slow rate. If the studies determine that there is a danger to the physical plant, then there are steps to take to minimize damage (e.g., low permeability concretes and special concrete coatings). These recommendations are relatively broad in keeping with the general nature of this report. We recommend consulting concrete experts to perform a more detailed analysis and to design a set of studies to determine the impacts of elevated $\mathrm{CO}_{2}$ on concrete carbonation rate.

\subsubsection{Dangers to the public}

The risk analysis in this report identifies three dangers to human safety; vessel sinking, drowning, and asphyxiation. Vessel sinking results in potential loss of human life and loss of expensive navigation assets and will prevent navigation traffic from passing the BRLD until the vessel can be raised. As with the dangers of elevated $\mathrm{CO}_{2}$ risks to the physical plant, there are no full-scale aeration systems to reference to determine impacts on human safety. However, a few study results for the effects of bubble plumes on human drowning and vessel sinking are available. The swimming pool industry knows of the asphyxiation effects of elevated $\mathrm{CO}_{2}$ in enclosed spaces. It is therefore reasonable to assume that human and vessel safety issues will be associated with the $\mathrm{CO}_{2}$ barrier system. Unlike studies to assess the effects of elevated $\mathrm{CO}_{2}$ on the physical plant, studies on dangers to the public and to navigation should be performed before the system is operated to ensure that unintended consequences will not occur. 


\section{Summary}

Available information indicates that an elevated $\mathrm{CO}_{2}$ barrier is a feasible solution for preventing the upstream spread of Asian carp at BRLD. No evidence was found to suggest that it would not work; although there are complications that occur because of the movement and mixing of water during vessel movement and lock operation. The environmental impacts of the barrier on non-target biota appear to be localized and minimal. Methods are available (e.g., aeration upstream and downstream of the barrier to purge elevated $\mathrm{CO}_{2}$ ) to localize and minimize barrier environmental impacts if significant environmental impacts are discovered. Although average daily flow rates through BRLD are low, intermittent passage of tows will create relatively high energy velocity fields (e.g., chamber emptying, prop wash, and water displacement by moving tows) that can affect the integrity of the $\mathrm{CO}_{2}$ bubble plume and create localized entraining conditions (e.g., wakes of barges and towboats, prop wash) that should be considered in the design of the barrier. Although difficult to assess because of a lack of information, it appears that elevated $\mathrm{CO}_{2}$ can corrode both concrete and metals associated with the physical plant of BRLD. These potential impacts should be monitored as part of initial testing. The most serious consequences of the elevated $\mathrm{CO}_{2}$ barrier are on human and vessel safety. Impacts on human safety should be considered prior to the operation of the elevated $\mathrm{CO}_{2}$ barrier. 


\section{References}

Adams, D. 2002. Methane hydrates: fire from ice. Nature 418:913-914. doi:10.1038/418913a.

Asian Carp Regional Coordinating Committee. 2014. http://www.asiancarp.us/news/.

Baylar, A., M. E. Emiroglu, and J. Ozturk. 2006. The development of Aeration performance with different typed nozzles in a vertical plunging water jet system. International Journal of Science and Technology 1(1):51-63.

Centers for Disease Control and Prevention (CDC). 2014. Carbon dioxide: Immediately dangerous to life or health concentrations (IDLHs). The National Institute for Occupational Safety and Health (NIOSH). Atlanta, GA: Centers for Disease Control and Prevention. http://www.cdc.gov/niosh/idlh/124389.html.

Chanson, H. 2008. Advective bubble diffusion of air bubbles in turbulent water flows. In Fluid Mechanics of Environmental Interfaces, ed. C. Gualtieri and D. T. Mihailovic, 163-196. The Netherlands, Leiden: Taylor and Francis.

Cohen, A. L., and M. Holcomb. 2009. Why corals care about ocean acidification: Uncovering the mechanism. Oceanography 22(4):118-127.

Colls, J. 2003. Freshwater acidification. Air Pollution. 2nd ed. New York: Taylor and Francis Group. http://www.air-quality.org.uk/13.php.

Devine, B. M., P. L. Munday, and G. P. Jones. 2012. Rising $\mathrm{CO}_{2}$ concentrations effect settlement behavior of larval damselfishes. Coral Reefs 31:229-238. doi:10.1007/s00338-011-0837-0.

Domenici, P., B. Allan, M. I. McCormickm, and P. L. Munday. 2012. Elevated carbon dioxide affects behavioral lateralization in a coral reef fish. Biology Letters 8:7881. doi:10.1098/rsbl.2011.0591.

Driscoll, C. T., G. B. Lawrence, A. J. Bulger, T. J. Butler, C. S. Cronan, C. Eagar, K. F. Lambert, G. E. Likens, J. L. Stoddard, and K. C. Weathers. 2001. Acidic deposition in the Northeastern United States: Sources and inputs, ecosystem effects, and management strategies. Bioscience 51(3):180-198.

Ewald, M. L., J. W. Feminella, K. K. Lenertz, and R. P. Henry. 2009. Acute physiological responses of the freshwater snail Elimia flava (Mollusca: Pleuroceridae) to environmental $\mathrm{pH}$ and calcium. Comparative Biochemistry and Physiology, Part C 150:237-245. doi:10.1016/j.cbpc.2009.05.001.

Fabry, V. J., B. A. Seibel, R. A. Feely, and J. C. Orr. 2008. Impacts of ocean acidification on marine fauna and ecosystem processes. ICES Journal of Marine Science 65:414-432.

Feely, R. A., C. L. Sabine, K. Lee, W. Berelson, J. Kleypas, V. J. Fabry, and F. J. Millero. 2004. Impact of anthropogenic $\mathrm{CO}_{2}$ on the $\mathrm{CaCO}_{3}$ system in the oceans. Science 305 (5682):362-266. doi:10.1126/science.1097329. 
George, K. S., and S. Nesic. 2007. Investigation of carbon dioxide corrosion of mild steel in the presence of Acetic Acid-Part 1: Basic Mechanisms. Corrosion 63(2):178186.

Hargrave, C. W., K. P. Gary, and S. K. Rosado. 2009. Potential effects of elevated atmospheric carbon dioxide on benthic autotrophs and consumers in stream ecosystems: a test using experimental stream mesocosms. Global Change Biology 15:2779-2790. doi:10.1111/j.1365-2486.2009.01897.x

Hornbach, D. J., and D. L. Childers. 1987. The effects of acidification on life-history traits of the freshwater clam Musculium partumeium (Say, 1822) (Bivalvia: Pisidiidae). Canadian Journal of Zoology 65:113-121.

HNTB Corporation. 2009. Vessel Allision Report I-7o Mississippi River Bridge: St. Louis, Missouri-East St. Louis, Illinois. http://newriverbridge.org/documents/plans/DraftVesselAllisionReport.pdf.

Hueschen, M. A. 2010. Can bubbles sink ships? American Journal of Physics 78:139. http://dx.doi.org/10.1119/1.3263819.

Jacobson, M. Z. 2005. Studying ocean acidification with conservative, stable numerical schemes for nonequilibrium air-ocean exchange and ocean equilibrium chemistry. Journal of Geophysical Research: Atmospheres 110:Do7302. doi:10.1029/2004JD005220.

Lagerblad, B. 2006. Carbon dioxide uptake during concrete life cycle - state of the art. Stockholm, Sweden: Swedish Cement and Concrete Research Institute.

McAliley, I. E., and P. D’Adamo. 2010. Reservoir Mixing to enhance raw water quality and treatability. http://www.ncsafewater.org/Pics/Training/AnnualConference/AC10TechnicalPapers/AC10_Wat er/Water_T.AM_11.00_McAliley.pdf.

Morin, G. 2014. Freshwater planted aquarium care and maintenance. Doctors Foster and Smith. Rhinelander, WI: Foster and Smith, Inc. http://www.drsfostersmith.com/PIC/article.cfm?dept_id=\&aid=765.

Nestler, J. M., G. R. Ploskey, G. Weeks, and L. Toni Schneider. 1995. Development of an operational, full scale fish protection system at a major pumped-storage hydropower dam. Hydropower '95: Proceedings of the International Conference on Hydropower, 25-28 July, San Francisco, CA, ed. J. J. Cassidy, 152-161. New York: American Society of Civil Engineers.

Nestler, J. M. 2014. Literature review of carbon dioxide $\left(\mathrm{CO}_{2}\right)$ barriers. Contract completion report for Subtask 3A Entitled "Literature Review of $\mathrm{CO}_{2}$ Barriers", Task Order Numbero010, Contract Number W912HZ-13-D-0004-001. Vicksburg, MS: U.S. Army Engineer Research and Development Center.

Orr, J. C., V. J. Fabry, O. Aumont, L. Bopp, S. C. Doney, R. A. Feely, A. Gnanadesikan, N. Gruber, A. Ishida, F. Joos, R. M. Key, K. Lindsay, E. Maier-Reimer, R. Matear, P. Monfray, A. Mouchet, R. G. Najjar, G.-K. Plattner, K. B. Rodgers, C. L. Sabine, J. L. Sarmiento, R. Schlitzer, R. D. Slater, I. J. Totterdell, M.-F. Weir, Y. Yamanaka, and A. Yool. 2005. Anthropogenic ocean acidification over the twenty-first century and its impact on calcifying organisms. Nature 437:681-686. 
Professional Pool Operators of America. 2010. Tech talk: $\mathrm{CO}_{2}$ - carbon dioxide, all it's gassed up to be. Professional Pool Operators of America. Newcastle, CA: Professional Pool Operators of America. http://ppoa.org/?page_id=453.

Research Designs and Standards Organization (RDSO) Lucknow. 2008. Technical literature on corrosion/carbonation protection in concrete structures. Government of India, Ministry of Railways (Railway Board). http://www.rdso.indianrailways.gov.in/uploads/files/1296881658250-bs_88.pdf.

Ricciardi, A., and H. J. MacIsaac. 2011. Impacts of biological invasions on freshwater ecosystems. Fifty years of invasion ecology: the legacy of Charles Elton, ed. D. M. Richardson, 211-224. Oxford, UK: Wiley-Blackwell.

Rice, S. A. 2004. Human health risk assessment of $\mathrm{CO}_{2}$ : Survivors of acute high-level exposure and populations sensitive to prolonged low-level exposure. In Third Annual Conference on Carbon Sequestration, Alexandria, VA. http://www.netl.doe.gov/publications/proceedings/04/carbon-seq/169.pdf

Scardina, P. 2004. Effects of dissolved gas supersaturation and bubble formation on water treatment plant performance. PhD Diss., Virginia Tech, Civil Engineering Department. http://scholar.lib.vt.edu/theses/available/etd-03252004084851/unrestricted/PaoloScardinaDissertation2004.pdf.

Scardina, P., and M. Edwards. 2001. Prediction and measurement of bubble formation in water treatment. Journal of Environmental Engineering 127:968-973.

Scheuhammer, A. M. 1991. Effects of acidification on the availability of toxic metals and calcium to wild birds and mammals. Environmental Pollution 71(2-4):329-375.

Schilt, C. R. 2007. Developing fish passage and protection at hydropower dams. Applied Animal Behaviour Science 104:295-325.

Schindler, D. W. 1988. Effects of acid rain on freshwater ecosystem. Science 239 (4836): 149-157. doi:10.1126/science.239.4836.149.

Scott, E. M., and K. W. Hevel. 1991. Upstream migration of sauger past Tennessee River dams via navigation locks. Knoxville, TN: Tennessee Valley Authority Water Resources Aquatic Biology Department.

Smith, D. L., J. M. Nestler, Thomas J. Maier. 2013. Planning guide for fish passage at Pittsburgh district dams. ERDC WQTN-AM-16. August 2013. Prepared for the Water Operations Technical Support (WOTS) Program. Vicksburg, MS: U.S. Army Engineer Research and Development Center.

Stewart, M. B., and E. W. Miner. 1987. Bubble dynamics in a turbulent ship wake. NRL Memorandum Report 6055. Washington, DC: Naval Research Laboratory.

Taft, E. P., B. N. Mochrie, T. Wright, and M. Bronoski. 1985. Preventing fish mortality at a large pumped storage plant. In Waterpower '85, 1815-1824.

U.S. Army Corps of Engineers (USACE). 1996. Rock Island District, Master Control Manual Brandon Road Lock and Dam 3-3. 
U.S. Army Corps of Engineers (USACE). 2012a Inventory of available controls for aquatic nuisance species of concern: Chicago area waterway system. Chicago, IL: U.S. Army Corps of Engineers, Chicago District.

http://glmris.anl.gov/documents/docs/ANS_Control_Paper.pdf.

U.S. Army Corps of Engineers (USACE). 2012b. Brandon Road Lock and Dam. Fact sheet. Rock Island, IL: U.S. Army Corps of Engineers, Rock Island District. http://www.mvr.usace.army.mil/Portals/48/docs/CC/FactSheets/IL/Brandon_Road_LockandD am.pdf.

U.S. Army Corps of Engineers (USACE). 2014. The GLMRIS Report: Great Lakes and Mississippi River interbasin study. Chicago, IL: U.S. Army Corps of Engineers, Chicago District. http://glmris.anl.gov/documents/docs/glmrisreport/GLMRIS_Report.pdf.

Wilcox, D. B., E. L. Stefanik, D. E. Kelner, M. A. Cornish, D. J. Johnson, I. J. Hodgins, S. J. Zigler, and B. L. Johnson. Improving Fish Passage Through Navigation Dams on the Upper Mississippi River System. Environmental Report 54, October 2004. Prepared for U.S. Army Engineer District, Rock Island, Rock Island, IL; U.S. Army Engineer District, St. Louis, St. Louis, MO; and U.S. Army Engineer District, St. Paul, St. Paul, MN.

http://www2.mvr.usace.army.mil/UMRS/NESP/Documents/ENV54_report.pdf (May 2004)

Wren, C. D., and G. L. Stephenson. 1991. The effect of acidification on the accumulation and toxicity of metals to freshwater invertebrates. Environmental Pollution 71:205-241.

Wuest, A., and A. Lorke. 2003. Small-scale hydrodynamics in lakes. Annual Review of Fluid Mechanics 35:373-412. doi:10.1146/annurev.fluid.35.101101.161220. 


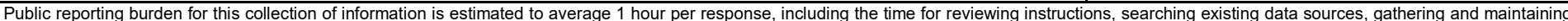

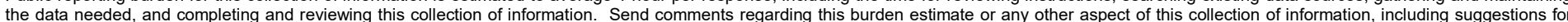

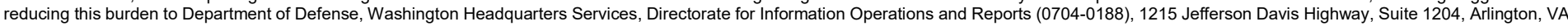

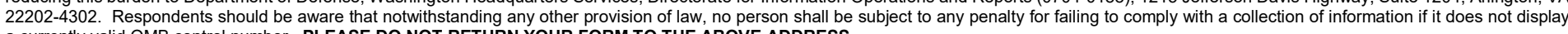
a currently valid OMB control number. PLEASE DO NOT RETURN YOUR FORM TO THE ABOVE ADDRESS.

\begin{tabular}{l|c}
$\begin{array}{l}\text { 1. REPORT DATE (DD-MM-YYYY) } \\
\text { September } 2017\end{array}$ & $\begin{array}{c}\text { 2. REPORT TYPE } \\
\text { Final report }\end{array}$ \\
\hline
\end{tabular}

\section{TITLE AND SUBTITLE}

Preliminary Feasibility and Risk Analysis of a Carbon Dioxide Barrier at Brandon Road Lock and Dam

\section{DATES COVERED (From - To)}

5a. CONTRACT NUMBER

5b. GRANT NUMBER

5c. PROGRAM ELEMENT NUMBER

\section{AUTHOR(S)}

John M. Nestler, David L. Smith, Christa M. Woodley, Robert D. Moser, and Pete C. Flanagan

5d. PROJECT NUMBER 450680

5e. TASK NUMBER

U4345698

5f. WORK UNIT NUMBER

8. PERFORMING ORGANIZATION REPORT NUMBER

ERDC TR-17-12

Environmental Laboratory

3909 Halls Ferry Road

Vicksburg, MS 39180-6199

9. SPONSORING / MONITORING AGENCY NAME(S) AND ADDRESS(ES)

Headquarters, U.S. Army Corps of Engineers

Washington, DC 20314-1000
10. SPONSOR/MONITOR'S ACRONYM(S)

11. SPONSOR/MONITOR'S REPORT NUMBER(S)

\section{DISTRIBUTION / AVAILABILITY STATEMENT}

Approved for public release; distribution unlimited.

\section{SUPPLEMENTARY NOTES}

\section{ABSTRACT}

A fish barrier using elevated aqueous carbon dioxide $\left(\mathrm{CO}_{2}\right)$ concentrations is proposed for Brandon Road Lock and Dam to prevent the spread of Asian carp into the Great Lakes. However, a $\mathrm{CO}_{2}$ barrier has never been assessed for potential environmental impacts, human health and safety risks, or for mechanical or structural deterioration of the lock and dam. Environmental impacts of the barrier will be modest and are restricted to the barrier vicinity. Nonetheless, significant asphyxia threats $\left(\mathrm{CO}_{2}\right.$ is denser than air) exist in closed spaces (e.g., barges, ship hulls, and the lock chamber when the miter gates are closed). Potential exists for drowning or vessel sinking because $\mathrm{CO}_{2}$ bubbles reduce water density and the buoyant forces needed to float a human body or vessel. The increased risk caused by the reduction in buoyancy cannot be estimated without first knowing the design and operation of the $\mathrm{CO}_{2}$ delivery system. Lastly, elevated aqueous $\mathrm{CO}_{2}$ concentrations will increase the concrete deterioration rate. However, little information exists that can be used to estimate the potential for structural or mechanical damage. Constructing an elevated $\mathrm{CO}_{2}$ barrier is feasible at the Brandon Roads Lock and Dam; however, this comes with potentially substantial risks to human health and safety, and project integrity. More detailed studies should be conducted after the design and operation of an elevated $\mathrm{CO}_{2}$ barrier is known.

\begin{tabular}{|c|c|c|c|c|c|}
\hline \multicolumn{2}{|l|}{ 15. SUBJECT TERMS } & \multicolumn{2}{|c|}{$\begin{array}{l}\text { Carbon Dioxide } \\
\text { Waterways } \\
\text { Hydraulic structures }\end{array}$} & \multicolumn{2}{|c|}{$\begin{array}{l}\text { Introduced organisms } \\
\text { Introduced organisms } \\
\text { nonindigenous aquatic pests }\end{array}$} \\
\hline \multicolumn{3}{|c|}{ 16. SECURITY CLASSIFICATION OF: } & $\begin{array}{l}\text { 17. LIMITATION } \\
\text { OF ABSTRACT }\end{array}$ & $\begin{array}{l}\text { 18. NUMBER } \\
\text { OF PAGES }\end{array}$ & $\begin{array}{l}\text { 19a. NAME OF RESPONSIBLE } \\
\text { PERSON }\end{array}$ \\
\hline $\begin{array}{l}\text { a. REPORT } \\
\text { UNCLASSIFIED }\end{array}$ & $\begin{array}{l}\text { b. ABSTRACT } \\
\text { UNCLASSIFIED }\end{array}$ & $\begin{array}{l}\text { c. THIS PAGE } \\
\text { UNCLASSIFIED }\end{array}$ & & 49 & $\begin{array}{l}\text { 19b. TELEPHONE NUMBER (include } \\
\text { area code) }\end{array}$ \\
\hline
\end{tabular}

